(C) This manuscript version is made available under the CC-BY-NC-ND 4.0 license https://creativecommons.org/licenses/by-nc-nd/4.0/

https://www.sciencedirect.com/science/article/pii/S1352231011004353

\title{
A review of uncertainties in atmospheric modeling of mercury chemistry I. Uncertainties in existing kinetic parameters - Fundamental limitations and the importance of heterogeneous chemistry
}

\author{
Mahamud Subir, Parisa A. Ariya, Ashu P.Dastoor
}

\begin{abstract}
Mercury and its related compounds are widely recognized as global pollutants. The accurate atmospheric modeling of its transport and fate has been the subject of much research throughout the last decade. Atmospheric gas, aqueous and heterogeneous chemistry are expected to occur for $\mathrm{Hg}$-containing specie sand accurate implementation of their chemical parameters is essential for realistic modeling of mercury cycling. Although significant progress has been made, the current state of knowledge of mercury chemistry exhibits numerous uncertainties. The objective of this two-part review is to explore the sources of uncertainty from the viewpoint of mercury chemistry. In this first part, we assess the discrepancy that exists in the currently available mercury kinetic parameters for the gas and aqueous phases. Theoretical and experimental approaches of rate constant determination exhibit various levels of limitation and accuracy. We present an overview of the available techniques and the assumptions and shortcomings associated with these methods in order to assist the atmospheric modellers. We review specific mercury oxidation and reduction reactions that have been investigated and are commonly implemented in mercury models with respect to the uncertainties associated with them. We reveal that for most of these mercury reactions our current state of knowledge reflects a lack of proper under-standing of their mechanisms. Atmospheric heterogeneity is a topic of great importance and we elaborate upon it in part II of this review.
\end{abstract}

\section{Introduction}

Mercury is widely recognized as a global pollutant and a serious health and environmental hazard (Pirrone and Mahaffey, 2005; Pirrone and Mason, 2009; Selin, 2009; Watras and Huckabee,1994 ). Released to the environment from a multitude of natural and anthropogenic sources, mercury is redistributed globally via a complex combination of chemical, physical, and biological processes throughout the atmosphere and the rest of the environment. Fig. 1 depicts some of the pathways by which mercury is chemically transformed and transported throughout the atmosphere. Processes such as oxidation/reduction reactions, complex formation, phase transitions, biodegradation, and surface and heterogeneous interactions with aerosols, clouds, snow, and ice convert mercury from one species to another. Physical mechanisms such as wind flux, runoff, and dry and wet deposition transport elemental and oxidized mercury species from one place to another (Pirrone and Mahaffey, 2005; Pirrone and Mason, 2009).

Given that selected mercury species, such as organomercury, are serious contaminants of the ecosystem and can have detrimental effects on human health (Flora et al., 1994; Selin, 2009), under-standing the detailed processes that govern the overall transport and cycling of mercury species has been a chief concern amongst environmental and atmospheric scientists. Accordingly, with the aim to simulate its transport and 
(C) This manuscript version is made available under the CC-BY-NC-ND 4.0 license https://creativecommons.org/licenses/by-nc-nd/4.0/

https://www.sciencedirect.com/science/article/pii/S1352231011004353

cycling, this recent decade has seen a surge of scientific research in the realm of atmospheric chemistry related to mercury (Pirrone and Mahaffey, 2005; Pirrone and Mason, 2009). Despite the extensive effort, however, accurate prediction of mercury transport at both regional and global scales remains challenging.

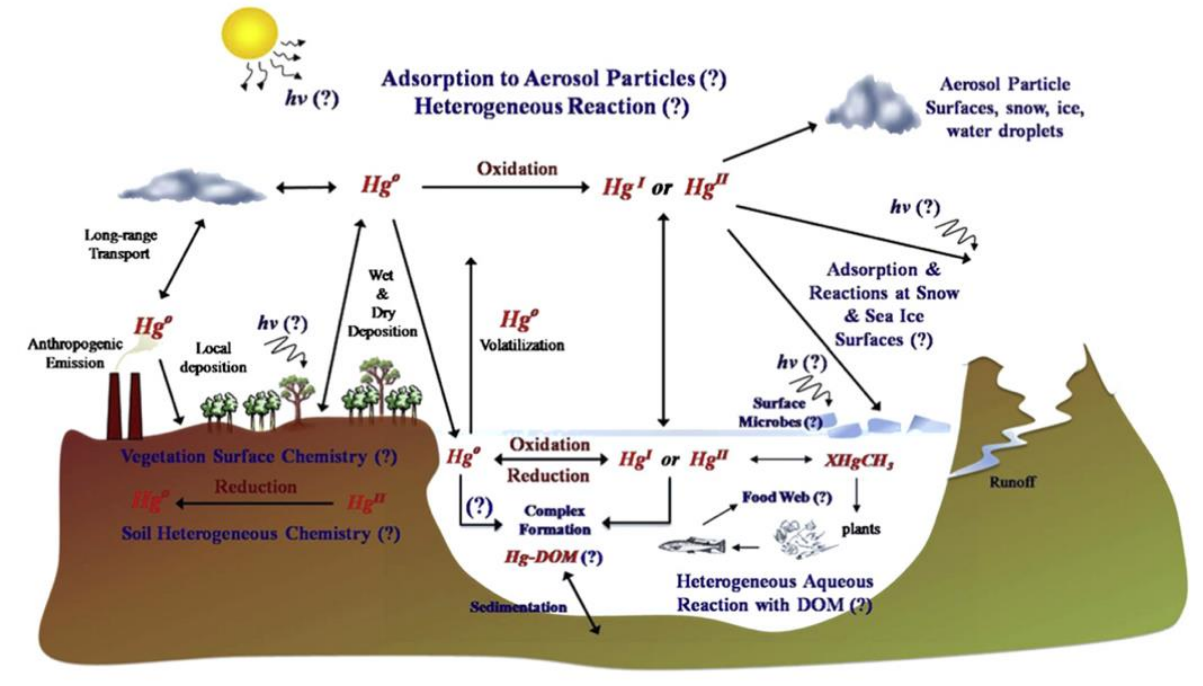

Fig. 1. Schematic of the mercury transport cycle.

Uncertainty in mercury modeling arises from many sources including: (1) inaccuracies present in existing chemical kinetic parameters, (2) inadequate representation of chemical processes and lack of characterization of mercury species critical in describing the cycling of mercury in the atmosphere, (3) lack of detailed mercury chemical speciation infield studies (4) difficulties at the boundary layer, (5) challenges with mercury transport and deposition mechanisms, (6) emission inventory, and (7) inherent assumptions in chemical models. The objective of this two-part review is to survey the sources of uncertainty associated with the modeling of mercury chemistry. Herein, we examine the discrepancies that exist within the currently available mercury kinetic data for gas and aqueous phase reactions (1). The chemical processes that are missing and/or inadequately implemented in mercury models (2), including the heterogeneous interaction of mercury (see Fig. 1) with aerosol, snow, ice, water droplets, vegetation surfaces, and dissolved organic matters (DOM), as well as reduction pathways, are discussed in part II.

Most of the different mercury gas and aqueous phase reaction rate constants available display large discrepancies (see Fig. 2) or are too limited to substantiate. Several recent publications have explored and addressed these kinetic studies (Ariya and Peterson,2005; Ariya et al., 2009b; Hynes et al., 2009; Lin et al., 2006). We herein extend the existing reviews beyond comparative studies of rate coefficients and focus on sources of uncertainties infield, experimental and theoretical studies for the available mercury reaction rate constants. We further discuss the implication of these uncertainties on modelling studies. 

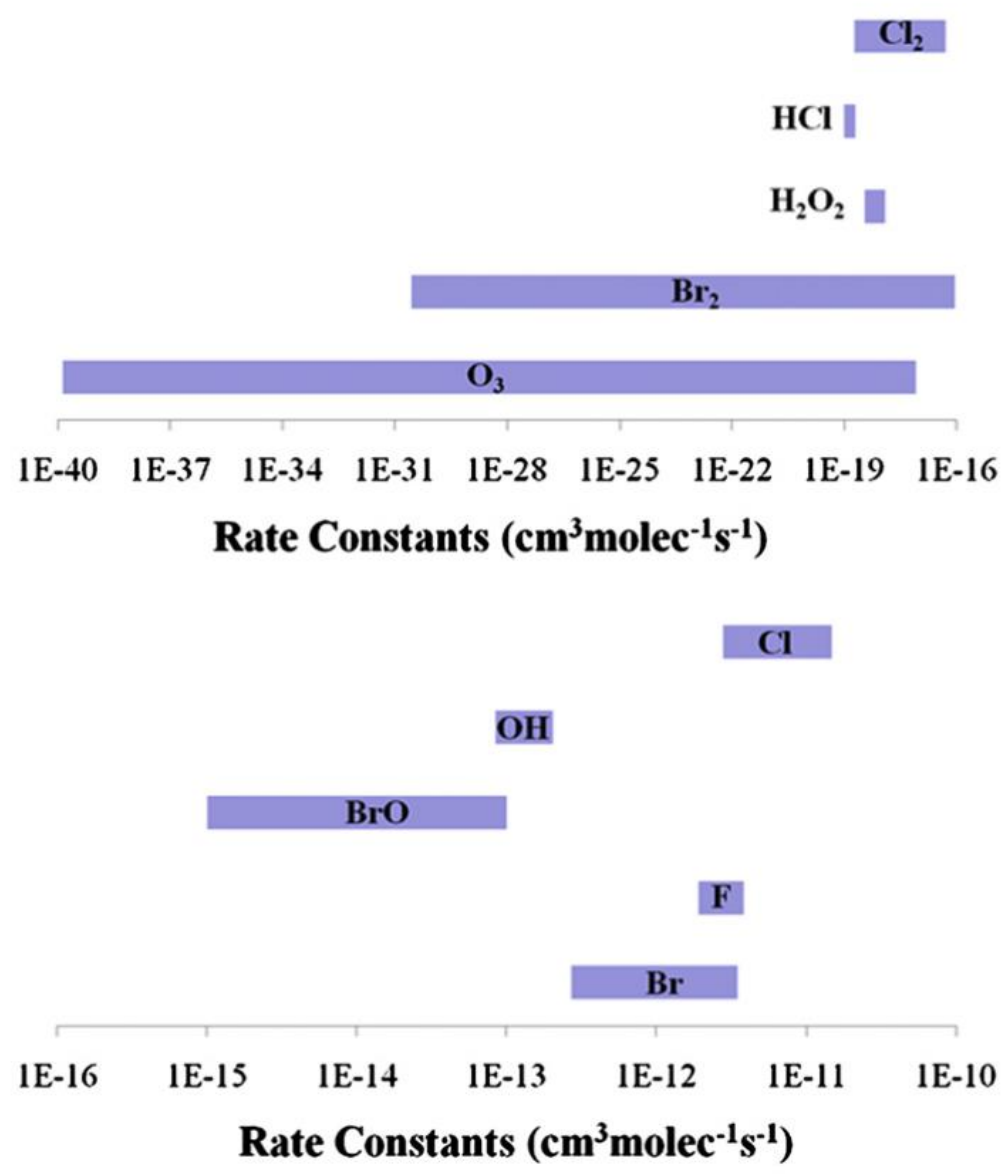

Fig. 2. Variability in the rate constants of selected mercury oxidation reactions.

\section{Chemical kinetics - fundamentals of experimental and theoretical methods}

The determination of rate constants, both theoretical and experimental, is complex and requires that assumptions be made. Usage of different kinds of measurement techniques and theoretical methods of calculations leads to different levels of uncertainty. A comprehensive knowledge of the assumptions pertaining to both experimental and theoretical techniques is thus necessary. In this section, we present a detailed overview of the limitations and assumptions associated with these approaches. A summary of the sources of uncertainty for different methods of rate constant determination is provided in Table 1. 
(C) This manuscript version is made available under the CC-BY-NC-ND 4.0 license https://creativecommons.org/licenses/by-nc-nd/4.0/

https://www.sciencedirect.com/science/article/pii/S1352231011004353

Table 1

Summary of experimental and theoretical methods of rate constant determination and their inherent assumptions leading to the uncertainty in measured or calculated values.

\begin{tabular}{|c|c|c|}
\hline $\begin{array}{l}\text { Methods of rate constant } \\
\text { determination }\end{array}$ & Description & Sources of uncertainty \\
\hline $\begin{array}{l}\text { Absolute rate method } \\
\text { (experimental) }\end{array}$ & $\begin{array}{l}\text { - Aims to measure the time evolution of } \\
\text { chemical species directly during a reaction } \\
\text { - Often employs the isolation method, where } \\
\text { the concentration of one reactant is held } \\
\text { much smaller than that of the other reactants } \\
\text { - Experimental setup includes a fast-flow tube } \\
\text { with different detection schemes }\end{array}$ & $\begin{array}{l}\text { - Experimental condition is typically at higher reactant } \\
\text { concentration and at lower pressure relative to } \\
\text { atmospheric conditions } \\
\text { - Often measures pseudo -reaction order and -rate constant } \\
\text { - Subject to interference from wall reactions as mercury } \\
\text { adsorbs onto the glass cell }\end{array}$ \\
\hline $\begin{array}{l}\text { Relative rate method } \\
\text { (experimental) }\end{array}$ & $\begin{array}{l}\text { - The rate constant of the reaction of interest } \\
\text { is obtained relative to the known rate constant } \\
\text { of a well-established reaction } \\
\text { - Appropriate for pseudo-first order reactions } \\
\text { - Experimental setup can be adjusted to monitor } \\
\text { or evade the effect of reaction chamber surfaces } \\
\text { - Experiment can be conducted at atmospheric conditions }\end{array}$ & $\begin{array}{l}\text { - The determined rate constant is only as good as the } \\
\text { original value of the reaction rate constant for the } \\
\text { reference molecule used } \\
\text { - Side or secondary reactions likely due to the presence } \\
\text { of reference molecule } \\
\text { - Subject to adsorption of mercury to the reaction chamber } \\
\text { wall but possible to minimize its affect by varying the } \\
\text { volume of the cell or coating it with hydrophobic material } \\
\text { - Additional experiments to ensure negligible side reactions } \\
\text { require varying the concentration/pressure of reactants, } \\
\text { carrying out the reactions in different bath gases, and } \\
\text { investigating the influence of scavengers by removing } \\
\text { reaction by-products or impurities. }\end{array}$ \\
\hline $\begin{array}{l}\text { Transitional state theory } \\
\text { (TST) (theoretical) }\end{array}$ & $\begin{array}{l}\text { - An approximate method in which the potential } \\
\text { energy surface (PES) is assumed to be the to be } \\
\text { the top of the reaction barrier represented by the } \\
\text { activation energy, } E_{a} \\
\text { - For unimolecular reactions, provides a rate constant } \\
\text { at the high pressure limit }\end{array}$ & $\begin{array}{l}\text { - Assumes all trajectories arising from reactants lead to } \\
\text { products and the motion along the reaction coordinate } \\
\text { can be treated classically } \\
\text { - The basic TST rate constants are considered as the upper } \\
\text { bound rate constant. However this challenge is rectified } \\
\text { using revised version of TST } \\
\text { - Determination of rate constants depends on the calculated } \\
\text { electronic or thermodynamic values. Thus, values obtained } \\
\text { without proper treatment of relativistic effects should not } \\
\text { be considered reliable }\end{array}$ \\
\hline $\begin{array}{l}\text { Rice-Ramsberger-Kassel-Markus } \\
\text { (RRKM) (theoretical) }\end{array}$ & $\begin{array}{l}\text { - An approximate treatment of reaction dynamics } \\
\text { - Applicable for unimolecular dissociation or recombination } \\
\text { reactions } \\
\text { - Not suitable to describe atom-atom recombination } \\
\text { reactions }\end{array}$ & $\begin{array}{l}\text { - Assumes that the energy of the excited reactant is randomly } \\
\text { distributed throughout all the available molecular states } \\
\text { - Determination of rate constants depends on the calculated } \\
\text { electronic or thermodynamic values. Thus values obtained } \\
\text { without proper treatment of relativistic effects should not } \\
\text { be considered reliable }\end{array}$ \\
\hline
\end{tabular}

\subsection{Uncertainties associated with experimental techniques}

In general, two types of rate determination methods ("absolute" and "relative")(Table 1) coupled to a variety of experimental setups and modes of detection are employed to measure kinetic parameters (Finlayson-Pitts and James N. Pitts, 1986; Levine, 2002). The absolute rate technique allows direct measurements of the rate constant but is not without shortcomings. For instance, in many cases it is difficult to hold one of the reactant concentrations constant as is necessary in determining a pseudo rate constant. Furthermore, reactions are often performed at a much higher reactant concentration and at lower pressure than what is found in the atmosphere. Therefore, extrapolation of the kinetic parameters to the atmospherically relevant condition is performed which potentially introduces uncertainties in the final reported values. In contrast, the relative rate method bears the advantage of being carried out under simulated tropospheric conditions. In this technique, however, the rate constant of the reaction of interest is obtained relative to a known rate constant of a well-established reaction. Hence, one of the major disadvantages of the relative rate approach is that the determined rate constant is only as good as the original value of the reaction rate constant for the reference molecule used. Thorough investigation involving several reference molecules to ensure negligible side or secondary reactions is critical to overcome this challenge 
(C) This manuscript version is made available under the CC-BY-NC-ND 4.0 license https://creativecommons.org/licenses/by-nc-nd/4.0/

https://www.sciencedirect.com/science/article/pii/S1352231011004353

\subsection{Validity of theoretical calculations involving mercury compounds}

Although theoretical studies are important and complementary to laboratory techniques, some theoretical calculations might not be adequate for mercury kinetic studies due to the inherent challenges associated with them. The theoretical determination of reaction parameters depends on molecular electronic structure and thermochemistry (Levine, 2002, 2009). Theoretical calculations of heats of formation, reaction enthalpies, and activation energies can assist in either supporting or refuting experimentally derived kinetic parameters and ultimately provide insight into the mechanism of chemical reactions. However, these calculations become challenging for multi-electron systems such as mercury (Ariya and Peterson, 2005; Levine, 2009; McQuarrie and Simon, 1997) since they are subject to relativistic effects; i.e. the inner shell electrons of an atom move very fast, close to the speed of light, and are thus significantly affected by the relativistic increase of mass with speed (Pyykko, 1988). The valence electrons can also experience relativistic effects due to their interaction with the inner shell electrons. Although these phenomena are typically neglected for atoms with atomic number less than 54 (Levine, 2009), they can have substantial influence on molecular properties such as bond lengths and binding energies of molecules containing atoms of high atomic number. In order to minimize calculation errors for mercury and mercury compounds, effort has been made and is still ongoing to treat the relativistic effects (Ariya and Peterson, 2005). Some of the approaches include all-electron methods and the implementation of pseudo-potentials, both of which have their shares of advantages and disadvantages (Levine, 2009; McQuarrie and Simon, 1997).

An earlier review (Ariya and Peterson, 2005) providing a detailed comparison of the theoretical approaches used for studying mercury has demonstrated that any electronic or thermodynamic values determined without the proper treatment of relativistic effects may not be considered accurate. Based on recent studies involving the ab initio thermochemistry of atmospheric mercury species (Balabanov and Peterson, 2003; Khalizov et al.,2003; Shepler et al., 2005; Tossel, 2003), it is clear that a higher level of theory incorporating core-valence electron correlation and augmented basis sets yields better results with accuracy of equal to or less than $1 \mathrm{kcal} \mathrm{mol}^{-1}$ from the high quality experimental data (Feller, 2007). The use of large basis sets CCSD(T) calculations has shown to provide very accurate results and is thus highly recommended for mercury related calculations. The thermodynamic changes in energy for selected gas phase reactions of mercury with atmospherically relevant compounds calculated using the CCSD(T)level of theory are listed in Table A.1. This table indicates that the discrepancy between theoretical and experimental values is smallest when a higher level of theory that incorporates relativistic effects is used. Additionally, it is important to emphasize that these values correspond only to pure gas phase chemical properties and that proper surface enhanced chemistry, which is often observed in laboratory experiments and relevant to atmospheric heterogeneity, has yet to be calculated using an adequate level of theory.

\subsection{Uncertainties associated with theoretical calculations of rate constant determination}


(C) This manuscript version is made available under the CC-BY-NC-ND 4.0 license https://creativecommons.org/licenses/by-nc-nd/4.0/

https://www.sciencedirect.com/science/article/pii/S1352231011004353

The most rigorous way to determine a reaction rate constant theoretically is to generate the complete potential energy surface (PES) for the reaction by solving the timeindependent electronic Schrodinger equation for a very large number of configurations for the nuclei. This is followed by quantum scattering or classical trajectory (CT) calculations for a wide variety of reactant states(Levine, 2002, 2009). This procedure is difficult and therefore simpler methods for the determination of reaction rate constants are often used. The transition state theory (TST) and the Rice-Ramsberger-KasselMarkus (RRKM) theory are, at present, the most commonly employed methods. Both the TST and the RRKM theories are approximate treatments of the reaction dynamics applicable to bimolecular reactions involving a barrier and unimolecular dissociation or recombination reaction, respectively(Levine, 2009; McQuarrie and Simon, 1997). Most of the current rate constants obtained are based on simple or modified TST and RRKM methods and thus carry some level of uncertainty (see Table 1).

The transition state theory, also known as the activated complex theory, eliminates the need for trajectory calculations and requires that PES be known only in the regions of the reactants and the transition state, typically assumed to be the top of the reaction barrier represented by the activation energy, $E_{a}$ (Levine, 2002,2009; McQuarrie and Simon, 1997). Other assumptions associated with TST are that all trajectories arising from reactants lead to products (Levine, 2009) and that the motion along the reaction coordinate can be treated classically as a translation. Ab initio data required for TST calculations are the activation energy and the equilibrium structure and harmonic vibrational frequencies of the reactants and the transition state. Re-crossing of the activated complex back to the reactants is also possible. As a result, TST tends to overestimate the rate constant for most atmospheric mercury reaction systems (Ariya and Peterson, 2005). The TST rate constant should generally be considered as the upper bound rate constant (Levine, 2002, 2009). A more improved rate constant is typically obtained using the generalized transition theory, i.e. canonical variational TST (VTST) in which the position of the transition state is varied to achieve the smallest rate constant. For unimolecular reactions, the TST provides a rate constant at the high pressure limit(Levine, 2002, 2009). For the fall-off region, the RRKM theory is applicable but entails certain assumptions. For example, RRKM theory requires that the energy of the excited reactant be randomly distributed throughout all the available molecular states. The molecule must thus be large enough to provide sufficient intra-molecular vibrational energy redistribution (Levine, 2002, 2009; McQuarrie and Simon, 1997). Consequently, the RRKM theory may not be suitable to describe atom-atom recombination reactions in which case quasi-classical trajectory calculations become more appropriate (Ariya and Peterson, 2005). Hence, the theoretical based kinetic parameters reported in the literature should not be considered as absolute values, i.e., without uncertainties, and awareness of these limitations is crucial when implementing them in mercury models.

3. Uncertainties in the existing mercury $\left(\mathrm{Hg}^{0}\right)$ oxidation reaction

Oxidation of elemental mercury, $\mathrm{Hg}^{0}$ to $\mathrm{Hg}^{\mathrm{I}}$ to $\mathrm{Hg}^{\mathrm{II}}$ species, is an important pathway in mercury cycling in the atmosphere because the oxidized species exhibit different physical and chemical properties. For instance, among other processes, vapor pressure, solubility (Clever et al., 1985; Hepler and Olofsson, 1975) and photochemistry (Kunkely et al., 1997; Zhang, 2006) of oxidized mercury compounds differ greatly from that of elemental mercury. Several experimental and theoretical investigations of $\mathrm{Hg}^{0}$ reaction with 
(C) This manuscript version is made available under the CC-BY-NC-ND 4.0 license https://creativecommons.org/licenses/by-nc-nd/4.0/

https://www.sciencedirect.com/science/article/pii/S1352231011004353

different atmospheric oxidants have been reported. A comparison of the theoretical and experimental rate constants of selected reactions in the range of $20^{\circ} \mathrm{C}-30^{\circ} \mathrm{C}(293-303 \mathrm{~K})$ is listed in Table A. 2 of the appendix. A comprehensive list of reactions can be found in (Ariya et al., 2009a). In this section, we survey and analyze the sources of error in some of the major mercury oxidation pathways. We discuss in the appendix the oxidation of $\mathrm{Hg}^{0}(\mathrm{~g})$ by other atmospheric reactants and reactions involving dissolved elemental mercury. Table 2 provides a summary of all the reactions with respect to the major uncertainties.

\subsection{Reaction with $\mathrm{OH}_{(\mathrm{g})}$ radical}

The available rate constants of $\mathrm{Hg}^{0}$ (g) oxidation by $\mathrm{OH}$ radicals $(\mathrm{OH})$ range from < $1.2 \times 10^{-13}$ (Bauer et al., 2003) to $9.0( \pm 1.3) \times 10^{-14} \mathrm{~cm}^{3} \mathrm{molec}^{-1} \mathrm{~s}^{-1}(\mathrm{Pal}$ and Ariya, 2004a; Sommar et al., 2001). The currently considered upper limit of these values, $1.2 \times 10^{-13}$ $\mathrm{cm}^{3}$ molec $^{-1} \mathrm{~s}^{-1}$, was obtained using laser induced fluorescence spectroscopy (LIFS) (Bauer et al., 2003), whereas the lower value rate constants (e.g., $9.0( \pm 1.3) \times 10^{-14} \mathrm{~cm}^{3} \mathrm{molec}^{-1} \mathrm{~s}^{-}$ ${ }^{1}$ ) were determined using the relative rate method (Pal and Ariya, 2004a; Sommar et al., 2001). The theoretical calculation using RRKM/B3LYP level theory resulted in a rate constant of $3.2 \times 10^{-13} \mathrm{~cm}^{3} \mathrm{molec}^{-1} \mathrm{~s}^{-1}$ (Goodsite et al., 2004). These three independently obtained experimental rate constants and the theoretically estimated values agree within an order of magnitude (Fig. 2). However, this observation does not imply that these values are applicable to reaction conditions in the atmosphere. It has been suggested that the rate constants obtained using the relative rate methods, initiated by photo-dissociation of an organic nitrite in mixtures of $\mathrm{Hg}^{0}(\mathrm{~g}), \mathrm{NO}$, air and various reference hydrocarbons, are over-estimated (Calvert and Lindberg, 2005) due to generation of ozone and possible side reactions. Because the atmospheric concentrations of these reactive species are much lower than in the laboratory environment, removal of elemental mercury by $\mathrm{OH}$ in the troposphere has been proposed to be much slower than predicted by the determined rate constants (Calvert and Lindberg, 2005;Goodsite et al., 2004). Moreover, a global scale modeling study(Bergan and Rodhe, 2001) suggested that the proposed reaction rate of $\mathrm{Hg}_{(\mathrm{g})}^{0}+\mathrm{OH}_{(\mathrm{g})}$ (Sommar et al., 2001) was too large by about a factor of three to be consistent with the observed seasonal cycle of $\mathrm{Hg}^{0}{ }_{(\mathrm{g})}$ in air. The reduction scheme in this model (Bergan and Rodhe, 2001) was rather limited. Since the atmospheric concentration of $\mathrm{Hg}^{0}(\mathrm{~g})$ is a net result of both oxidation and reduction reactions, the lack of consideration for reduction pathways in models can lead to inaccurate conclusion about the implemented oxidation rate constant. 
(C) This manuscript version is made available under the CC-BY-NC-ND 4.0 license

https://creativecommons.org/licenses/by-nc-nd/4.0/

https://www.sciencedirect.com/science/article/pii/S1352231011004353

Table 2

Summary of mercury reactions - the available range of rate constants and comments on the corresponding uncertainty and implication to modeling.

\begin{tabular}{|c|c|}
\hline Reactions & Range of rate constants \\
\hline $\begin{array}{l}\text { Gas phase oxidation } \\
\mathrm{Hg}_{(\mathrm{g})}^{0}+\mathrm{OH}_{(\mathrm{g})}\end{array}$ & $\begin{array}{l}\left(\mathrm{cm}^{3} \mathrm{molec}^{-1} \mathrm{~s}^{-1}\right) \\
\sim 10^{-13} \text { to } \sim 10^{-14} \text { (exp.) } \sim 10^{-13} \\
\text { (theo.) }\end{array}$ \\
\hline $\mathrm{Hg}_{(\mathrm{g})}^{0}+\mathrm{O}_{3(\mathrm{~g})}$ & $\begin{array}{l}\sim 10^{-18} \text { to } \sim 10^{-20} \text { (exp.) }(293 \\
\mathrm{K} \leq T \leq 303 \mathrm{~K}) \sim 10^{-40} \text { (theo.) }\end{array}$ \\
\hline $\mathrm{Hg}_{(\mathrm{g})}^{0}+\mathrm{Cl}_{(\mathrm{g})}$ & $\begin{array}{l}\sim 10^{-11} \text { to } \sim 10^{-13} \text { (exp.) } \sim 10^{-12} \\
\text { (theo.) }\end{array}$ \\
\hline $\mathrm{Hg}_{(\mathrm{g})}^{0}+\mathrm{Br}_{(\mathrm{g})}$ & $\begin{array}{l}\sim 10^{-12} \text { to } \sim 10^{-13} \text { (exp.) } \sim 10^{-12} \\
\text { to } \sim 10^{-13} \text { (theo.) }\end{array}$ \\
\hline $\mathrm{Hg}_{(\mathrm{g})}^{0}+\mathrm{F}_{(\mathrm{g})}$ & NRO (exp.) $\sim 10^{-12}$ (theo.) \\
\hline $\mathrm{Hg}_{(\mathrm{g})}^{0}+\mathrm{I}_{(\mathrm{g})}$ & NRO (exp.) \\
\hline $\mathrm{Hg}_{(\mathrm{g})}^{0}+\mathrm{BrO}_{(\mathrm{g})}$ & $\sim 10^{-13}$ to $\sim 10^{-15}$ (exp.) \\
\hline $\mathrm{Hg}_{(\mathrm{g})}^{0}+\mathrm{ClO}_{(\mathrm{g})}$ & $\sim 10^{-17}$ (exp.) \\
\hline $\mathrm{Hg}_{(\mathrm{g})}^{0}+\mathrm{HCl}_{(\mathrm{g})}$ & $\sim 10^{-19}$ (exp.) \\
\hline $\mathrm{HgCl}_{(\mathrm{g})}+\mathrm{HCl}_{(\mathrm{g})}$ & $\sim 10^{-26}$ to $\sim 10^{-33}$ (theo.) \\
\hline $\mathrm{Hg}_{(\mathrm{g})}^{0}+\mathrm{H}_{2} \mathrm{O}_{2(\mathrm{~g})}$ & $\sim 10^{-16}$ to $\sim 10^{-19}$ (exp.) \\
\hline $\mathrm{Hg}_{(\mathrm{g})}^{0}+\mathrm{F}_{2(\mathrm{~g})}$ & $\sim 10^{-15}$ (exp.) \\
\hline $\mathrm{Hg}_{(\mathrm{g})}^{0}+\mathrm{Cl}_{2(\mathrm{~g})}$ & $\sim 10^{-17}$ to $\sim 10^{-19}$ (exp.) \\
\hline $\mathrm{Hg}_{(\mathrm{g})}^{0}+\mathrm{Br}_{2(\mathrm{~g})}$ & $\begin{array}{l}\text { NRO to }<10^{-17} \text { (exp.) } \sim 10^{-31} \\
\text { (theo.) }\end{array}$ \\
\hline $\mathrm{Hg}_{(\mathrm{g})}^{0}+\mathrm{I}_{2(\mathrm{~g})}$ & $<10^{-19}$ (exp.) \\
\hline $\mathrm{Hg}_{(\mathrm{g})}^{0}+\mathrm{NO}_{3(\mathrm{~g})}$ & $<10^{-15}$ (exp.) \\
\hline $\begin{array}{l}\text { Aqueous phase oxidation } \\
\mathrm{Hg}_{(\mathrm{aq})}^{0}+\mathrm{O}_{3(\mathrm{aq})}\end{array}$ & $\begin{array}{l}\mathrm{M}^{-1} \mathrm{~s}^{-1} \\
\sim 10^{7}\end{array}$ \\
\hline $\mathrm{Hg}_{(\mathrm{aq})}^{0}+\mathrm{OH}_{(\mathrm{aq})}$ & $\sim 10^{9}$ to $\sim 10^{10}$ \\
\hline $\mathrm{Hg}_{(\mathrm{aq})}^{0}+\left(\mathrm{HOCl}_{(\mathrm{aq})}, \mathrm{OCl}_{(\mathrm{aq})}^{-}\right)$ & $\sim 10^{6}$ \\
\hline $\mathrm{Hg}_{(\mathrm{aq})}^{+}+\left(\mathrm{Br}_{2(\mathrm{aq})}, \mathrm{HOBr}_{(\mathrm{aq})}, \mathrm{OBr}_{(\mathrm{aq})}^{-}\right)$ & $\sim 10^{-1}$ \\
\hline
\end{tabular}

Remarks

The mechanism of this reaction is unclear. It is apparent that formation of stable intermediate due to third-body collision and/or presence of surface make this reaction possible. Surface influence of this reaction must be further investigated

This reaction may be influenced by chamber surfaces or third-body collisions. Gas phase oxidation is unlikely based on theoretical calculations and the mechanism of the reaction is unclear. Influence of atmospheric surfaces and heterogeneity must be studied

The discrepancy in the rate constants is mainly due to different experimental techniques used. However, multiple independent relative rate studies yield a rate constant in the order of $10^{-11}$. Additional studies are required to reduce the uncertainty

The discrepancy is subject to differences in techniques. Uncertainties in radical concentration profile along with heterogeneous reactions also play a role May not be of great significance in earth atmosphere

Limited data available

Complex reactions are likely. Mechanism of this reaction needs to be elucidated. Influence of atmospheric heterogeneity should be investigated. Boundary layer and free troposphere $\mathrm{BrO}$ concentration profile is speculative and is the major uncertainty for this reaction

Limited data available

Limited data available for temperature applicable to atmospheric conditions. The reaction is slow and given trace level of $\mathrm{HCl}$ in atmosphere, its importance is negligible. This reaction is however important for plume chemistry at high temperature for which rate constants are available, see (Ariya et al., 2009a)

Limited data available with large discrepancy. Possibility of heterogeneous reaction exists. Mechanism of this reaction is not known. Further investigations required Limited data available. May not be significant in atmosphere

The existing data exhibits large discrepancies due to use of different methods and possible surface catalysis. Nonetheless, reaction is too slow and its contribution in removing $\mathrm{Hg}_{(\mathrm{g})}^{0}$ is negligible

The two available experimental data show no evidence or very slow reaction. Theoretical calculation also predicts slow reaction. However, other pathways may initiate this reaction. Further studies should be pursued but not a priority. Although limited data exist, the reaction is too slow to have impact on atmospheric mercury oxidation.

This reaction has the potential to be important. However, the limited data available provides only an upper limit. The mechanism and influence of atmospheric heterogeneity should be studied.

General Comment: The data on aqueous phase oxidation is scarce relative to the data available on gas phase oxidation. The important oxidation pathways in aqueous phase, based on the fast reaction rate constants, are that of the reaction with ozone and hydroxyl radical. Re-evaluation of these values as a function of different environmental conditions is desirable. The fast oxidation by $\mathrm{O}_{3}$ and $\mathrm{OH}$ in aqueous phase, compared to the corresponding reaction in the gas phase, indicate that surface mediated oxidation of mercury can also be significant. Further investigation of oxidation on the surface of the aerosol and air/water interface is necessary.

Aqueous phase reduction

$\mathrm{Hg}_{(2 \mathrm{q})}^{2+}+\mathrm{HO}_{2(\mathrm{aq})}$

NA vs. $\sim 10^{4}$

$\mathrm{Hg}_{(\mathrm{aq})}^{2+}+\mathrm{O}_{2(\mathrm{aq})}^{-}$

Although reduction of $\mathrm{Hg}^{2+}$ (aq) to $\mathrm{Hg}^{+}$(aq) is fast, the viability of the subsequent reduction to $\mathrm{Hg}_{(\mathrm{aq})}^{0}$ in atmospheric condition has been questioned because re-oxidation of $\mathrm{Hg}^{+}(\mathrm{aq})$ occurs rapidly

$\mathrm{HgSO}_{3 \text { (aq) }}$ (decomposition) $\quad \sim 10^{-1}$ to $\sim 10^{-2} \mathrm{~s}^{-1}$

$\mathrm{Hg}\left(\mathrm{SO}_{3}\right)_{2(2 \mathrm{aq})}^{2-} \rightarrow \mathrm{Hg}_{(\mathrm{aq})}^{0}+\mathrm{S}(\mathrm{VI}) \quad<<10^{-4} \mathrm{~s}^{-1}$

Discrepancy attributed to different rate measurement techniques

Too slow to be of significant importance in mercury cycling. However, many other reduction pathways in heterogeneous conditions are not systematically studied and/or are not represented in mercury models. See part II of this review for details. 
(C) This manuscript version is made available under the CC-BY-NC-ND 4.0 license https://creativecommons.org/licenses/by-nc-nd/4.0/

https://www.sciencedirect.com/science/article/pii/S1352231011004353

The extent of the $\mathrm{Hg}_{(\mathrm{g})}^{0}+\mathrm{OH}_{(\mathrm{g})}$ reaction and its implication for the atmospheric removal of elemental gaseous mercury becomes more uncertain when the mechanism of this reaction is evaluated. When the formation of the product for this reaction, gaseous mercuric oxide, $\mathrm{Hg}^{0}(\mathrm{~g})$, is considered, it is apparent that this reaction is unlikely to occur in the gas phase as the production of $\mathrm{Hg}^{0}$ (g) is highly endothermic (Tossel, 2003).

Theoretical consideration (Goodsite et al., 2004; Tossel, 2003) of the binding energy of $\mathrm{HgOH}^{+}$, a possible intermediate, implies that this species will rapidly dissociate to its reactants, $\mathrm{OH}$ radical, under atmospheric conditions and that the removal of gaseous elemental mercury by $\mathrm{OH}_{(\mathrm{g})}$ should not be a significant process in the atmosphere. It is also possible that $\mathrm{HgOH}^{+}$exhibits complex reaction mechanisms and produces stable products. Indeed, product studies for the oxidation of mercury by $\mathrm{OH}$ and $\mathrm{O}_{3}(\mathrm{Pal}$ and Ariya, 2004a; Snideret al., 2008) show evidence of solid mercuric oxide, $\mathrm{HgO}_{(\mathrm{s})}$, rather than $\mathrm{HgO}_{(\mathrm{g})}$ formation and enhanced chain growth of $\mathrm{HgO}_{(\mathrm{s})}$ on a carbon grid at a relative humidity of 50\% (see Fig. A.1). These findings clearly indicate that surfaces play a key role for this reaction. Therefore, the determined rate constant cannot be solely attributed to pure gas phase chemistry since experiments were influenced by surface reactions (Ariya et al., 2009a).

\subsection{Reaction with $\mathrm{O}_{3(\mathrm{~g})}$}

A wide range of rate constants for the reaction of gas phase mercury with ozone is reported in the literature (Fig. 2, Table A.2). The rate constant for the $\mathrm{Hg}^{0}{ }_{(\mathrm{g})}+\mathrm{O}_{3(\mathrm{~g})}$ reaction currently used in most models, for which it is known that the reaction was occurring in both the gas phase and on the reactor walls, is $3( \pm 2) \times 10^{-20} \mathrm{~cm}^{3} \mathrm{molec}^{-1} \mathrm{~s}^{-1}$ at $20^{\circ} \mathrm{C}$ (Hall, 1995). By modifying the surface of the reaction vessel and by carrying out the reaction in a much larger reaction chamber, the effect of the wall on the rate constant has been greatly reduced in more recent experiments (Pal and Ariya,2004b; Snider et al., 2008; Sumner et al., 2011, 2005), so that the rate constant determined was in the order of $10^{-19}$ $\mathrm{cm}^{3} \mathrm{molec}^{-1} \mathrm{~s}^{-1}$. The use of large reaction chambers $\left(17 \mathrm{~m}^{3}\right)$ and low reactant concentrations (Sumner et al., 2011, 2005) renders the rate constants obtained free of surface effects and relevant to atmospheric concentrations. These independent studies showed evidence of reaction products adsorbing to the wall of the reaction chamber, forming clusters and aerosols as exemplified in Fig. A.1.

A sensitivity study using the rate constant from Hall (1995) indicated that the reaction was too slow to account for the majorpart of the removal of $\mathrm{Hg}^{0} \mathrm{~g}$ f from the atmosphere (Bergan and Rodhe, 2001). While maintaining all other base parameters, the implementation of this rate constant obtained in (Pal and Ariya,2004b) resulted in an unrealistically low concentration of $\mathrm{Hg}_{(\mathrm{g})}^{0}, 0.3-1.2 \mathrm{ng} \mathrm{m}^{-3}$, with a shorter lifetime of 11 days compared toa lifetime of 9 months obtained from the base results (Seigneuret al., 2006). In addition to the fact that these modeling exercises did not implement a detailed reduction scheme, several reasons for the shorter atmospheric lifetime of $\mathrm{Hg}^{0}{ }_{(\mathrm{g})}$ due to the fast rate constant have been suggested. These include (1) the possibility that this rate constant depicts an upper bound of the $\mathrm{Hg}_{(\mathrm{g})}^{0}+\mathrm{O}_{3(\mathrm{~g})}$ reaction due to reactions with the wall, (2) that this fast oxidation is compensated for by other atmospheric reduction mechanisms that have yet to be discovered, and (3) that current global emissions are 
(C) This manuscript version is made available under the CC-BY-NC-ND 4.0 license https://creativecommons.org/licenses/by-nc-nd/4.0/

https://www.sciencedirect.com/science/article/pii/S1352231011004353

perhaps underestimated and that a larger emission flux could be consistent with the faster $\mathrm{Hg} 0$ (g)oxidation rate by ozone (Seigneuret al., 2006).

According to some theoretical studies (Shepler and Peterson,2003; Tossel, 2003), the production of $\mathrm{HgO}_{(\mathrm{g})}$, a potential product of the reaction between $\mathrm{Hg}^{0}{ }_{(\mathrm{g})}$ and $\mathrm{O}_{3(\mathrm{~g})}$, appears to be unlikely in the pure gas phase. Quantum mechanical calculations of the molecular properties of $\mathrm{HgO}_{(\mathrm{g})}$ suggest that the gas phase reaction $\mathrm{Hg}_{(\mathrm{g})}^{0}+\mathrm{O}_{3(\mathrm{~g})} \rightarrow \mathrm{HgO}_{(\mathrm{g})}$ $+\mathrm{O}_{2(\mathrm{~g})}$ is highly endothermic by approximately $90 \mathrm{~kJ} \mathrm{~mol}^{-1}$. Calculation of the free energy change and an equilibrium constant for this reaction using this value shows (Hynes et al., 2009) that oxidation of mercury by ozone is unlikely to proceed as a homogeneous gas phase reaction. In fact, QCIS(T)/MP2 along with transition state theory yields a rate constant on the order of $10^{-40} \mathrm{~cm}^{3} \mathrm{molec}^{-1} \mathrm{~s}^{-1}$ for this reaction. The discrepancy between the theoretical and the experimental values is due to the fact that the theory employs the thermodynamics of bond dissociation and formation of the reactants and products in the pure gas phase whereas laboratory experiments are subject to complex reactions taking place in the presence of other reactants and surfaces. Thus, a direct comparison is not viable.

Experimentally, high resolution microscopy techniques confirmed the major product of $\mathrm{Hg}^{0}(\mathrm{~g})$ oxidation by ozone to be solid mercuric oxide, $\mathrm{HgO}_{(\mathrm{s})}$, predominantly adsorbed on the reactor walls and not $\mathrm{HgO}_{(\mathrm{g})}$ (Ariya et al., 2009a; Pal and Ariya, 2004b; Snider et al., 2008)(Fig. A.1). HgO in the gas phase was not observed. This fact alone precludes us from comparing the experimentally determined rate constant to that of the pure gas phase theoretical studies. A recent theoretical result (Tossel, 2006) also suggests that stable oligomers of mercury oxide, $(\mathrm{HgO})_{\mathrm{n}}$, can subsist and their formation on surfaces is very likely. Furthermore, complex reactions with reactive species present in the atmosphere are also possible. For example, a direct proportionality in the rate constant with an increase in $\mathrm{CO}$ concentration has been reported (Snider et al., 2008) which clearly demonstrates a third-body effect on the gas phase $\mathrm{Hg}_{(\mathrm{g})}+\mathrm{O}_{3(\mathrm{~g})}$ reaction. The net rate constant for this reaction was found to be $6.2( \pm 1.1) \times 10^{-19} \mathrm{~cm}^{3} \mathrm{molec}^{-1} \mathrm{~s}^{-1}$ in that investigation with an additional $20 \%$ error due to uncertainties associated with instrumental accuracy. Moreover, the effect of surface reactions could not be overruled in this study (Snider et al., 2008).

It can be deduced that pure gas phase oxidation of elemental mercury by ozone may not occur in the atmosphere. However, third-body effects and/or atmospheric heterogeneity or surfaces can induce the collisions necessary to enhance the rate of this reaction by making the formation of the intermediates and products more favorable. Alternative mechanisms for this reaction can exist that would make this reaction potentially viable in the atmosphere. It has been proposed (Calvert and Lindberg, 2005) that the reaction may proceed by the formation of a gas-phase inter-mediate, $\mathrm{HgO}_{3(\mathrm{~g})}$, which then decomposes to $\mathrm{OHgOO}_{(\mathrm{g})}$ and there-after transforms to $\mathrm{HgO}_{(\mathrm{s})}$ and $\mathrm{O}_{2(\mathrm{~g})}$ as is consistent with laboratory experiments (Snider et al., 2008). Due to its very high Henry's constant $\left(2.69 \times 10^{12} \mathrm{M} \mathrm{atm}^{-1}\right), \mathrm{HgO}_{(\mathrm{s})}$ is readily found in sea salt particles where it is rapidly converted to $\mathrm{Hg}^{2+}{ }_{\text {(aq) }}$ ions, which can form complexes with $\mathrm{Cl}^{-}$ions to produce $\mathrm{HgCl}_{2 \text { (aq) }}$ (Hedgecock and Pirrone, 2005; Schroeder and Munthe, 1998). Water molecules and aerosols containing halides can stabilize the formation of certain products and thereby enhance ozone mediated oxidation of elemental mercury. The reaction of $\mathrm{HgO}_{(\mathrm{g})}$ with water is highly exergonic (Tossel, 2003) and the formation of oxidized 
(C) This manuscript version is made available under the CC-BY-NC-ND 4.0 license https://creativecommons.org/licenses/by-nc-nd/4.0/

https://www.sciencedirect.com/science/article/pii/S1352231011004353

mercury halides is favored in the presence of water (Shepler et al., 2007b). This latter point strongly emphasizes the fact that the description of mercury chemistry in the atmosphere must take into account the influence of heterogeneous surfaces of water droplets, snow, ice and aerosols.

\subsection{Reactions with atomic halogen - $\mathrm{Cl}_{(\mathrm{g})}$ and $\mathrm{Br}(\mathrm{g})$}

Reactions of mercury with atomic halogen species yield thermodynamically favorable mercury halide products in the gas phase (Khalizov et al., 2003; Tossel, 2003). Many theoretical (Goodsiteet al., 2004; Khalizov et al., 2003; Shepler et al., 2007a) and experimental (Donohoue et al., 2006; Greig et al., 1970a,b; Horneet al., 1968; Senior et al., 2000) studies have been dedicated to understanding the oxidation reaction of mercury by $\mathrm{Cl}$ and Bratoms. Their results are highlighted and discussed in recent reviews (Ariya et al., 2009a; Hynes et al., 2009). For the purpose of brevity, we discuss in this review only the kinetic parameters used in current and up-to-date global chemical transport simulations (Dastoor and Davignon, 2009; Lin et al., 2006; Seigneur et al., 2009). Using the LIFS technique, the kinetic coefficient of the $\mathrm{Hg} 0(\mathrm{~g})$ and $\mathrm{Cl}(\mathrm{g})$ recombination based on a three body collision model has been determined (Donohoue et al., 2005). At $25 \mathrm{C}$, a rate coefficient of $5.4 \times 10^{-13} \mathrm{~cm}^{3} \mathrm{molec}^{-1} \mathrm{~s}^{-1}$ was obtained (Donohoue et al.,2005). This result is much slower than the rate constant of $1.0( \pm 0.2) \times 10^{-11} \mathrm{~cm}^{3} \mathrm{molec}^{-1} \mathrm{~s}^{-1}$ previously obtained using a relative rate method (Ariya et al., 2002). In a more recent study, using a much larger reaction chamber $\left(17 \mathrm{~m}^{3}\right)$ and a much lower reactant concentration, an even faster rate constant, $8.4( \pm 1.1) \times 10^{-11} \mathrm{~cm}^{3} \mathrm{molec}^{-1} \mathrm{~s}^{-1}$, for $\mathrm{Hg}_{(\mathrm{g})}{ }$ and $\mathrm{Cl}_{(\mathrm{g})}$ reaction has been obtained (Sumner et al., 2011).

The rate constant obtained by the relative rate method (Ariya et al., 2002) exhibited a large uncertainty. The major source of discrepancy is that the relative rate method may provide only an upper limit of the rate constant due to secondary reactions in the presence of reference molecules and surface effects from the reaction chamber walls. Determination of the rate constant using several different reference molecules is necessary. These issues were addressed in the recent study by carrying out the reaction using low reactant concentrations in a $17.3 \mathrm{~m}^{3}$ Teflon-wall chamber. The relative rate study was carried out using two different reference molecules for which consistent results were obtained (see Table A.1). Thus, the authors pointed out that the evidence of a faster action cannot be attributed to side reactions or in appropriateness of the relative rate method for this reaction. As for the LIFS study, the main source of uncertainty arose from the determination of Clatom concentration which was estimated from the concentration of $\mathrm{Cl}_{2}$ and the photolysis laser flux. The authors discuss other complications such as the presence of $\mathrm{O}_{2}$, which can lead to the formation of $\mathrm{ClO} 2$, and the dissociation of the reaction product $\mathrm{HgCl}_{2}$ into $\mathrm{Hg}$ and $\mathrm{Cl}_{2}$ (Donohoue et al., 2005; Hynes et al., 2009). Similar to the oxidation reaction of mercury with ozone, the availability of a broad range of experimentally measured rate coefficients for the reaction between $\mathrm{Hg}^{0}{ }_{(\mathrm{g})}$ and $\mathrm{Cl}$ indicates a large level of uncertainty. However, $\mathrm{Cl}$ atom concentration is too low to have a significant influence on $\mathrm{Hg}^{0}(\mathrm{~g})$ depletion in the atmosphere (Ariya et al., 2002; Hynes et al., 2009).

For the reaction of $\mathrm{Br}_{\text {with } \mathrm{Hg}^{0}}{ }_{(\mathrm{g})}$, the relative rate method (Ariya et al., 2002) yielded a rate constant of $3.2( \pm 0.3) \times 10^{-12} \mathrm{~cm}^{3} \mathrm{molec}^{-1} \mathrm{~s}^{-1}$. A rate constant of $3.6( \pm 0.3)$ $\times 10^{-13} \mathrm{~cm}^{3}$ molec $^{-1} \mathrm{~s}^{-1}$ was determined by LIFS (Donohoue et al., 2006; Hynes et al., 2009). 
(C) This manuscript version is made available under the CC-BY-NC-ND 4.0 license https://creativecommons.org/licenses/by-nc-nd/4.0/

https://www.sciencedirect.com/science/article/pii/S1352231011004353

Once again, these values are subject to the advantages and disadvantages of their respective techniques as discussed for the reaction of $\mathrm{Cl}$ and $\mathrm{Hg}^{0}{ }_{(\mathrm{g})}$. The applicability of the relative rate method for this reaction using different reference molecules under environmental conditions has also been tested and a rate constant of $6.4( \pm 4.7) \times 10^{-13}$ $\mathrm{cm}^{3}$ molec ${ }^{-1} \mathrm{~s}^{-1}$ hasbeen recently reported (Sumner et al., 2011). Computational studies (Goodsite et al., 2004; Khalizov et al., 2003; Shepler et al., 2007a) have provided a rate constant on the order of $10^{-13}-10^{-12} \mathrm{~cm}^{3} \mathrm{molec}^{-1} \mathrm{~s}^{-1}$ for this reaction. Based on these values and the possible atmospheric halogen atom concentrations, the recombination of $\mathrm{Hg} 0(\mathrm{~g})$ and $\mathrm{Br}$ atoms can serve as a pathway for mercury depletion in the Arctic troposphere. Based on its fast reaction rate and relatively high concentration, atomic $\mathrm{Br}$ is thought to be a key player in polar mercury depletion events (Ariya and Ryzhkov, 2003; Holmes et al., 2006). Bromine induced oxidation of mercury is also evident in the mid-latitudes (Ariya, 2010; Obrist et al., 2011). However, atmospheric Br concentration in the upper troposphere and the marine boundary layer (MBL) is a subject of great scientific debate. The global importance of $\mathrm{Br}$ reactions has yet to be properly evaluated as there is a lack of understanding of the horizontal and vertical concentration profiles of oxidized mercury and halogens.

\section{Uncertainties in the existing mercury reduction rate constants}

Reduction of mercury $\left(\mathrm{Hg}^{\mathrm{I}}\right.$ and $\mathrm{Hg}^{\mathrm{II}}$ species) is assumed to occur in the aqueous phase, where mercury can exist as free ions or complexes (Pirrone and Mahaffey, 2005; Pirrone and Mason, 2009). Table A.3 provides aqueous reduction reactions and their corresponding rate constants that are generally incorporated in atmospheric mercury modeling (Hedgecock and Pirrone, 2005; Lin et al.,2006; Seigneur et al., 2009, 2006). The importance of the reduction of mercury with hydroperoxyl radical (HO2), long thought as significant (Pehkonen and Lin, 1998), has been rebuked in a more recent study (Gardfeldt and Jonsson, 2003) which deems the viability of this reaction at ambient conditions to be negligible. A laboratory kinetic study (Pehkonen and Lin,1998) with photolysis of oxalate ion as the source of $\mathrm{HO}_{2}$ found the rate constant for the reduction of mercury by $\mathrm{HO}_{2}$ to be $1.7 \times 10^{4} \mathrm{M}^{-1} \mathrm{~s}^{-1}$ when no chloride was present and $1.1 \times 10^{4} \mathrm{M}^{-1} \mathrm{~s}^{-1}$ in the presence of chloride ions. A two-step reduction model with the production of $\mathrm{Hg}^{1+}$ as the intermediate was proposed. Under the assumption that $\mathrm{Hg}^{1+}$ is unstable in the aqueous phase (Pehkonen and Lin, 1998), it was concluded that the $\mathrm{HO}_{2}$ radical readily oxidized $\mathrm{Hg} 2$ pinaqueous solutions. On the other hand, the determination of reduction potentials using the pulse radiolysis technique (Gardfeldt and Jonsson, 2003) demonstrated that the reduction of $\mathrm{Hg}^{2+}$ by $\mathrm{HO}_{2}$ radical is unlikely to occur under environmental conditions because the reduction potentials of $\mathrm{Hg}^{2+}$ species are much lower than that of the corresponding reduction potential of oxygen. The fast re-oxidation of $\mathrm{Hg}^{+}{ }_{\text {(aq) }}$ in the presence of molecular oxygen will dominate (Nazhat and Asmus, 1973). The same conclusion is applicable to the reduction of $\mathrm{Hg}^{2+}$ by $\mathrm{O}^{2-}$ radicals (Gardfeldt andJonsson, 2003). These authors, however, suggest that formation ofHg0can occur via photolytic fragmentation of an organic ligand bound to $\mathrm{Hg}^{2+}$ under actinic radiation. The elimination

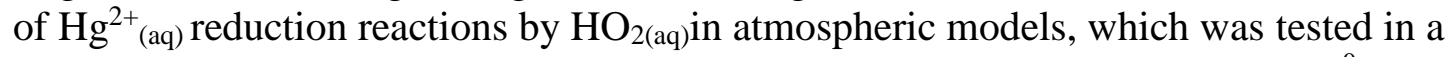
sensitivity study (Seigneur et al., 2006), results in a surface concentration of $\mathrm{Hg}^{0}$ that is lower by factor of two to four compared to the concentration of $\mathrm{Hg}^{0}$ typically observed. 
(C) This manuscript version is made available under the CC-BY-NC-ND 4.0 license https://creativecommons.org/licenses/by-nc-nd/4.0/

https://www.sciencedirect.com/science/article/pii/S1352231011004353

Eliminating $\mathrm{Hg}^{2+}$ reduction by $\mathrm{HO}_{2}$ radical in a previous study (Bullock,2004) also led to low modeling performance.

Another pathway for mercury reduction generally implemented in atmospheric models is the decomposition of $\mathrm{HgSO}_{3(\mathrm{aq})}$ via an intramolecular reduction. The rate of this reaction was measured by trapping the $\mathrm{Hg}^{0}$ product as $\mathrm{Hg}^{2+}$ and monitoring the UV spectrum of $\mathrm{HgSO}_{3(\mathrm{aq})}$ and $\mathrm{Hg}^{2+}$ at $\mathrm{pH} 3$ and $25^{\circ} \mathrm{C}$ (Van Loon et al., 2000). The rate constant obtained in this study is about 50 times smaller than previously suggested (Munthe et al., 1991). The discrepancy has been attributed to the difference in the rate measurement approaches. In the more recent study, a direct approach was used to measure the rate constant and accordingly a new mechanism was proposed in which no net $\mathrm{Hg}^{+}$or sulphite radical anions are generated. The authors also investigated the effect of temperature on this reaction which showed that the rate constant quadruples for each $10^{\circ} \mathrm{C}$ rise in temperature. Given the temperature variability in the aqueous environment of cloud droplets, atmospheric models commonly employ their result (Van Loon et al., 2000). The reduction by $\mathrm{Hg}\left(\mathrm{SO}_{3}\right)_{2}{ }^{2-}$ and photo-reduction of $\mathrm{Hg}(\mathrm{OH})_{2}$ are too slow and are usually not considered (Lin et al., 2006; Lin and Pehkonen, 1999). The major source of uncertainty regarding mercury reduction is that only a limited number of reduction pathways have been identified. Reduction is assumed to be taking place only in the aqueous phase. However, reduction of oxidized mercury on atmospheric surfaces of aerosols, ice, snow, and water droplets and in heterogeneous mixtures of soil and aquatic dissolved organic matters are typically not considered. Part II of this review discusses the potential importance of these surfaces and heterogeneity (see Fig. 1).

\section{Concluding remarks}

There are several factors that lead to uncertainties in the existing mercury reaction rate constants and thereby in the modeling of atmospheric mercury cycling. Table 2 summarizes the uncertainties associated with these reactions. The theoretical calculation of rate constants involving mercury requires extensive treatment of the relativistic effects and accurate determination of bond energies of reactants, reaction intermediates, and products. Furthermore, assumptions associated with TST and RRKM theory lead to uncertainty in the theoretically determined rate constants. Experimental determination of rate constants often involves indirect measurements of the changes in concentration of the reacting species, intermediates, and products as it is difficult to detect the concentration of mercury in the reaction vessel that is not representative of the surfaces and heterogeneity present in the atmosphere. With the current state-of-the-art techniques available for determining rate constants, these assumptions and difficulties define the minimum level of uncertainties in the existing rate constants. Additional sources of uncertainties that hinder realistic representation of $\mathrm{Hg}^{0}{ }_{(\mathrm{g})}$ oxidation in the atmosphere for mercury modeling are as follows: the mechanisms of most of these reactions are not well understood, the influence of atmospheric surfaces and heterogeneity are not known and/or not taken into account, in certain cases reliable concentration profiles of the reacting species are not well characterized, and, lastly, the effects of atmospheric variables such as temperature, solar radiation, etc. on the rate of reaction are not well studied.

Given the relatively high abundance of ozone in the atmosphere, it is plausible that it plays an important role in $\mathrm{Hg}^{0}{ }_{(\mathrm{g})}$ oxidation. However, it is clear that oxidation of 
(C) This manuscript version is made available under the CC-BY-NC-ND 4.0 license https://creativecommons.org/licenses/by-nc-nd/4.0/

https://www.sciencedirect.com/science/article/pii/S1352231011004353

$\mathrm{Hg}^{0}{ }_{(\mathrm{g})}$ by ozone exclusively in the gas phase does not occur. Laboratory experiments along with theoretical investigations, however, strongly suggest that third-body effects and surfaces, i.e. solid $\mathrm{HgO}$ formation (Snider et al.,2008), not only make this reaction possible in the atmosphere but can also enhance it. A similar conclusion applies to the reaction of $\mathrm{Hg}^{0}{ }_{(\mathrm{g})}$ with $\mathrm{OH}$ radicals. Both ozone and $\mathrm{OH}$ radicals are present in the urban, remote, and MBL regions of the atmosphere. Their reaction should not be eliminated from mercury models. Instead, research should be directed towards understanding the effects of atmospherically relevant surfaces on the rate of these reactions. Modeling sensitivity studies to reflect the surface effects should also be performed.

Oxidation reactions of $\mathrm{Hg}^{0}(\mathrm{~g})$ with atomic halogens are significantly faster compared to reactions with molecular species. The availability of atomic halogens in the MBL makes these reactions important but the relatively low concentration of atomic halogens in urban and remote areas implies that these reactions are not significant in removing $\mathrm{Hg}_{(\mathrm{g})}^{0}$ in these regions. The greatest uncertainty in the likelihood and the degree of oxidation of $\mathrm{Hg}^{0}(\mathrm{~g})$ taking place in the atmosphere lies not in the discrepancy in the rate constants of these reactions but in the uncertain vertical tropospheric concentration profiles of the species involved, namely, $\mathrm{Br}, \mathrm{BrO}, \mathrm{Cl}$, and also $\mathrm{Hg}^{0}{ }_{(\mathrm{g})}$ and oxidized mercury. The primary step in reducing uncertainty for reactions involving these species should entail accurate measurements of these species throughout the atmosphere. Until then, sensitivity studies can provide information with regard to the significance of mercury oxidation by atomic halogens relative to oxidation via $\mathrm{OH}$ radicals and ozone.

Implications of the oxidation of $\mathrm{Hg}^{0}$ (g) by other reactants, as discussed in the appendix, are as follows. Hydrogen peroxide is available at relatively high concentrations throughout the atmosphere but not enough experimental and theoretical data exists regarding its reactivity with $\mathrm{Hg}_{(\mathrm{g})}^{0}$. Empirical observations do indicate that removal of $\mathrm{Hg}^{0}{ }_{(\mathrm{g})}$ in the presence of $\mathrm{H}_{2} \mathrm{O}_{2}$ is enhanced in the surface of snow (Lahoutifard et al., 2003, 2006). Hence, future research should be directed to elucidate the mechanism and surface effects for such reactions. The significance of $\mathrm{Hg}^{0}{ }_{(\mathrm{g})}$ oxidation by molecular halogen species is small since the pure gas phase oxidation of $\mathrm{Hg}^{0}(\mathrm{~g})$ by $\mathrm{F}_{2}, \mathrm{Cl}_{2}, \mathrm{Br}_{2}$, and $\mathrm{I}_{2}$ as well as atomic $\mathrm{F}$ and $\mathrm{I}$ are slow. Considering the relatively low abundance of these species in the atmosphere, the incorporation of these reactions in the mercury models can be neglected, except in selected cases where the local or regional effects of such reactions might prevail. Finally, knowledge of oxidation reactions of dissolved mercury (Table A.3) is also limited and not without uncertainty. It is evident however (see Appendix) that oxidation of $\mathrm{Hg}^{0}$ in the aqueous phase occurs faster than in the gas phase. This is a crucial indication that $\mathrm{Hg}^{0}$ oxidation can be rapid when mercury is in contact with water or adsorbed at various surfaces, pointing to the importance of more elaborate reduction schemes in atmospheric models.

Based on our discussions on experimental evidence and theoretical insights into the mechanisms of reactions and the influence of surfaces, it is apparent that various natural surfaces and atmospheric heterogeneity play an important role in the oxidation of gaseous mercury. The lack of knowledge of mercury surface chemistry hinders realistic modeling of the mercury cycle. Due to the fact that there is a local increase in the reacting species at a given surface and that surfaces render the formation of certain intermediates and products of reactions favorable, most reactions are, in general, enhanced in the presence of surfaces. It is probable that mercury oxidation will proceed more quickly in 
(C) This manuscript version is made available under the CC-BY-NC-ND 4.0 license https://creativecommons.org/licenses/by-nc-nd/4.0/

https://www.sciencedirect.com/science/article/pii/S1352231011004353

the atmosphere than in the pure gas phase. This would imply that the removal of mercury from the atmosphere occurs more rapidly than is now presently thought. Consequently, the reduction of $\mathrm{Hg}^{\mathrm{I}}$ and $\mathrm{Hg}^{\mathrm{II}}$ species to $\mathrm{Hg}^{0}$ occurring in the aqueous phase and the eventual release of $\mathrm{Hg}^{0}$ to the gas phase is omnipresent not only in environmental water but also in the atmosphere, i.e., in rain, clouds, and aerosols and other heterogeneous interfaces. Reduction processes thus become significant in order to forecast a mercury global lifetime which currently ranges from 0.5 to 2 years excluding much faster transformations in the marine boundary layer, salt lakes, and polar regions. The role of atmospheric surfaces and heterogeneity, along with other chemical processes that are implemented inadequately or not at all, is the subject of part II of this review.

\section{Appendix}

\section{A.1 Uncertainties in the existing mercury $\left(\mathrm{Hg}^{0}\right)$ oxidation rate constants}

\section{A.1.1 Reaction with $F_{(g)}$ and $I_{(g)}$}

The reaction between $\mathrm{F}$ atoms and $\mathrm{Hg}^{0}$ (g) in the atmosphere is considered to be unimportant because the lifetime of $\mathrm{F}$ atoms with respect to the reaction with water vapor, even below $10 \%$ relative humidity, is less than $1 \mathrm{~ms}$ (Sumner et al., 2005). The reaction of $\mathrm{Hg}_{(\mathrm{g}) \text { With I }}$ atoms has been studied (Greig et al., 1970b) using kinetic absorption spectroscopy to monitor transient $\mathrm{HgI}$ upon direct photolysis of $\mathrm{CF} 3 \mathrm{I}$ in the presence of $\mathrm{HgO}(\mathrm{g})$. No quantitative result was obtained because a sufficient amount of $\mathrm{HgI}$ was not produced. The authors concluded from this observation that the combination reaction between atomic iodine and mercury is very slow due to fast recombination of iodine atoms. The inclusion of fluorine and iodine radical chemistry is not necessary in chemical transport models except for in I radical rich environments as observed in Antarctica.

\section{A.1.2 Reaction with $\mathrm{BrO}_{(\mathrm{g}) \text { and } \mathrm{ClO}_{(\mathrm{g})}}$}

The rate constants for the reaction of $\mathrm{Hg}^{0}$ (g) and $\mathrm{BrO}$ have been determined by relative rate methods (Raofie and Ariya, 2003) with values varying from $10^{-15}-10^{-13} \mathrm{~cm}^{3} \mathrm{molec}^{-1} \mathrm{~s}^{-1}$ due to the presence of different reference molecules. Product studies of this reaction suggest the formation of $\mathrm{Hg}^{1+}, \mathrm{Hg}^{2+}, \mathrm{HgBr}, \mathrm{HgO}$, and $\mathrm{HgBrO}$ or $\mathrm{HgOBr}$ (Raofie and Ariya, 2004). Similar to the formationof $\mathrm{HgO}_{(\mathrm{g})}$, the formation of $\mathrm{HgBr}_{(\mathrm{g})}$ is endothermic. Thus, these authors pointed out that the fast kinetic rate may result from a secondary, more complex pathway, particularly as samples wereisolated on surface grids, which precludes a pure gas phase chemistry. A more recent study, carried out in a $17 \mathrm{~m}^{3}$ Teflon environmental chamber and with reactants concentration 2 orders of magnitude lower compared to the previous study (Raofie andAriya, 2003), has obtained a rate constant of $1.8( \pm 1.0) \times 10^{-14} \mathrm{~cm}^{3}$ molecules ${ }^{-1} \mathrm{~s}^{-1} \mathrm{BrO}$ mediated oxidation (Sumner et al.,2011 ). The experimental setup eliminated wall influence on there action and the reproducibility of the previous result establishes reliability of the rate constant. However, the mechanism by which this reaction proceeds is unclear because the production of $\mathrm{HgO}$ in the pure gas phase from the reactions of mercury with $\mathrm{BrO}$ is energetically unfavourable. Formation of $\mathrm{HgBrO}$, which has been determined to be exothermic, can provide an alternative pathway for mercury oxidation (Balabanov and Peterson, 2003; Shepler and Peterson, 2003; Tossel, 2003). In addition to the kinetic and mechanistic uncertainties in the $\mathrm{BrO}$ reaction, the influence of atmospheric heterogeneity and in the vertical profile of $\mathrm{BrO}$ in the boundary layer and free troposphere makes 
(C) This manuscript version is made available under the CC-BY-NC-ND 4.0 license https://creativecommons.org/licenses/by-nc-nd/4.0/

https://www.sciencedirect.com/science/article/pii/S1352231011004353

the significance of this reaction speculative. For the reaction with $\mathrm{ClO}_{(\mathrm{g})}$ the only available rate constant available is $9.9 \times 10^{-17} \mathrm{~cm}^{3}$ molecules $^{-1} \mathrm{~s}^{-1}$ (Sumneret al., 2011). The rate constant was obtained using a relative rate method under similar condition as the $\mathrm{BrO}$ reaction (Sumner et al.,2011); thus, very likely to be free of wall-effect. This value is too small to have great impact on mercury oxidation.

\section{A.1.3 Reaction with $\mathrm{HCl}_{(\mathrm{g})}, \mathrm{H}_{2} \mathrm{O}_{2}(\mathrm{~g})$, and $\mathrm{NO}_{3}(\mathrm{~g})$}

Gaseous $\mathrm{HCl}$ is present at trace concentrations in the atmosphere and its reaction with elemental gaseous mercury is slow, $1 \times 10^{-19} \mathrm{~cm}^{3}$ molecules $^{-1} \mathrm{~s}^{-1}$ (Hall and Bloom, 1993). Mercury models incorporate this rate constant (Hedgecock and Pirrone,2005; Seigneur et al., 2006). The only experimentally derived gas phase rate constant of the $\mathrm{Hg}^{0}(\mathrm{~g})+\mathrm{H}_{2} \mathrm{O}_{2(\mathrm{~g})}$ reaction is estimated to be between $3.5 \times 10^{-19} \mathrm{~cm}^{3}$ molecules ${ }^{-1} \mathrm{~s}^{-1}$ and $8.5 \times 10^{-19} \mathrm{~cm}^{3}$ molecules ${ }^{-1} \mathrm{~s}^{-1}$ in an $\mathrm{N}_{2}$ atmosphere at $20^{\circ} \mathrm{C}$ (Tokos et al.,1998). Using an FEP reactor chamber along with detection by CVAFS the authors assigned the latter value as the upper limit. This value is 3 orders of magnitude smaller than what has been previously assumed (Seignuer et al.,1994). There is no other experimental or theoretical data available for this reaction. Consequently, it is difficult to gauge the validity of this commonly used (Lin et al., 2006; Pai et al., 1997; Seigneur et al., 2006) kinetic parameter. The gas phase product of this reaction is not known. However, $\mathrm{Hg}^{\mathrm{II}}$ adsorbed to the walls of the chamber was observed. The possibility of heterogeneous oxidation of elemental mercury is very likely since an increase in mercury deposition on the acidic snowpack containing the photochemical oxidant $\mathrm{H}_{2} \mathrm{O}_{2}$ under solar irradiation has been observed (Lahoutifard et al., 2003, 2006). The detailed mechanism of this reaction is not known.

The rate constant of mercury oxidation with $\mathrm{NO}_{3}$ radical has been reported to be $\left\langle 4 \times 10^{-15}\right.$ $\mathrm{cm}^{3}$ molecules ${ }^{-1} \mathrm{~s}^{-1}$ an absolute rate method using a fast-flow setup (Sommar et al., 1997). The reaction studied was subject to wall-effects and thus, this value has been considered as an upper limit by the authors. There were no product studies done and the reaction was assumed to proceed through the formation of $\mathrm{HgO}_{(\mathrm{g})}$ and $\mathrm{NO}_{2(\mathrm{~g})}$, which has been pointed out to be thermodynamically unfavourable (Hynes et al., 2009). A subsequent relative rate study (Sumner et al., 2005) carried out in an environmental chamber $\left(17.3 \mathrm{~m}^{3}\right)$, which reduces surface effects significantly, obtained a rate constant of $<7 \times 10^{-15} \mathrm{~cm}^{3}$ molecules $\mathrm{s}^{-1}$. Products of the reactions were not monitored. Consequently, the mechanism of $\mathrm{Hg}^{0}(\mathrm{~g})$ Oxidation by nitrate radical is lacking. Since NO3is a photochemical reactant and exhibit variable concentration up to $100 \mathrm{pptv}$ (Levine, 1985), it can have realistic impact on mercury oxidation, especially when heterogeneous chemistry is involved. Further investigations in regard to surface effects and mechanism of this reaction are desirable.

\section{A.1.4 Reaction with $\mathrm{Cl}_{2}(\mathrm{~g}), \mathrm{Br} 2(\mathrm{~g}), \mathrm{I}_{2}(\mathrm{~g})$, and $\mathrm{F}_{2}(\mathrm{~g})$}

The commonly used rate constant in the mercury modeling community (Lin et al., 2006; Seigneur et al., 2006) for the reaction of gaseous mercury with molecular chlorine, $2.6 \times 10^{-18}$ $\mathrm{cm}^{3}$ molecules ${ }^{-1} \mathrm{~s}^{-1}$ (Ariya et al., 2002), was obtained by absolute rate methods using CVAAS and GC-MS under pseudo-first order conditions with respect to $\mathrm{Hg}^{0}{ }_{(\mathrm{g})}$. This value is about a factor of 2 slower than the previously reported rate constant of $4.8 \times 10^{-18} \mathrm{~cm}^{3}$ molecules ${ }^{-1} \mathrm{~s}^{-1}$ (Calhoun and Prestbo, 2001), also used as a model parameter (Bullock, 2005). For various concentrations of $\mathrm{Hg}^{0}{ }_{(\mathrm{g})}$ and $\mathrm{Cl}_{2(\mathrm{~g})}$, rate constants of $9.8-50 \times 10^{-18} \mathrm{~cm}^{3}$ molecules ${ }^{-1} \mathrm{~s}^{-1}$ 1have been reported (Sumner et al., 2005). Earlier kinetic studies (Medhekaret al., 1979; Menke and Wallis, 1980; Schroeder et al., 1991; Seignuer et al., 1994; Skare and Hohansson, 1992; Sliger et al.,2000) yielded rate 
(C) This manuscript version is made available under the CC-BY-NC-ND 4.0 license https://creativecommons.org/licenses/by-nc-nd/4.0/

https://www.sciencedirect.com/science/article/pii/S1352231011004353

constants that were influenced by surface catalysis and should be considered as upper limits (Ariya et al.,2009a,b). The major product of the reaction was determined to be $\mathrm{HgCl}_{2(\mathrm{~s})}$ adsorbed onto the wall of the reaction chamber (Ariya et al., 2002, 2008). A more recent study (Yan et al., 2005) determined the rate constant of the oxidation of $\mathrm{Hg}^{0}$ (g) by $\mathrm{Cl}_{2}$ using a mercury photodetection technique using three reactors. These reactors had different surface area to volume ratios for the purpose of separating concurrent gas phase, surface induced, and photo-induced reaction pathways. The 2nd order reaction rate constant of $\mathrm{Hg}^{0}{ }_{(\mathrm{g})}$ with $\mathrm{Cl}_{2}$ in the gas phase was estimated to be $1.82( \pm 0.05) \times 10^{-19} \mathrm{~cm}^{3} \mathrm{molecules}^{-1} \mathrm{~s}^{-1}$ at $1 \mathrm{~atm}$ and $297 \pm 1 \mathrm{~K}$. The one order of magnitude discrepancy in the rate constant of this result with that produced in (Ariya et al., 2002) was attributed to the different degrees and methods of consideration of surface-catalyzed and photo-induced reactions by the authors.

Even when the upper limit of these gas-phase rate constants is used, it is apparent that the contribution of this reaction to the removal of gaseous elemental mercury in the atmosphere is negligible due to the low concentration of $\mathrm{Cl}_{2}$ in the atmosphere. The same is true for the reaction of $\mathrm{Hg}^{0}$ (g) with $\mathrm{Br}_{2}$. The upper limit rate constant for this reaction is $\leq 9( \pm 2) \times 10^{-17}$ $\mathrm{cm}^{3}$ molecules $\mathrm{s}^{-1} \mathrm{~s}^{-1}$ at $298 \mathrm{~K}$ (Ariya et al., 2002). Another study (Sumner et al., 2005) reported no evidence of mercury loss in the presence of $\mathrm{Br}_{2}$ with varying relative humidity and mercury and bromine concentration. The insertion reaction, $\mathrm{Hg}_{(\mathrm{g})}+\mathrm{Br}_{2(\mathrm{~g})} \rightarrow \mathrm{HgBr}_{2(\mathrm{~g})}$, has a large barrier and very small rate constant. However, other recombination reactions with $\mathrm{Br}$ atom and $\mathrm{HgBr}$ or $\mathrm{BrHg}$ species are sufficiently fast to serve as the initiation steps for oxidation of mercury in the atmosphere (Balabanov et al., 2005) (see Table A.1).

For the oxidation of gaseous elemental mercury by $\mathrm{F}_{2}$ and $\mathrm{I}_{2}$, the rate constants obtained are $1.8 \times 10^{-15} \mathrm{~cm}^{3}$ molecules ${ }^{-1} \mathrm{~s}^{-1}$ (Sumner et al., 2005) and $<1.27 \times 10^{-19} \mathrm{~cm}^{3}$ molecules $^{-1} \mathrm{~s}^{-1}$ (Raofie et al., 2008), respectively. The reaction with $\mathrm{I}_{2}$ is slow and considered to have negligible impact on atmospheric mercury. The products of this reaction were determined to be $\mathrm{HgI}_{2}$ and $\mathrm{HgOI}$. Although the rate constant for the reaction with molecular fluorine implies an atmospheric $\mathrm{Hg}^{0}(\mathrm{~g})$ half-life of 0.8 years (Sumner et al.,2005), there are no other reported measurements of this reaction for comparison. This study also found that in the presence of UV irradiation the reaction between $\mathrm{Hg}_{(\mathrm{g})}^{0}$ and $\mathrm{F}_{2}$ comes to a halt which the authors believe to be due to the rapid reaction of $\mathrm{F}$ atoms, formed from photolysis of $\mathrm{F}_{2}$, with water vapor.

\section{A.2 Oxidation of dissolved elemental mercury}

Dissolved elemental mercury compounds in environmental waters can undergo chemical reactions that have different rates relative to reaction rates in the pure gas phase. Elemental mercury oxidation by $\mathrm{O}_{3}$ and $\mathrm{OH}$ has been observed to be faster in the aqueous phase compared to the gas phase (Gardfeldt et al., 2001;Iverfeldt and Lindqvist, 1986; Lin and Pehkonen, 1997; Munthe,1992 ). The currently available data on mercury oxidation in the aqueous phase is limited and those that are available have yet to be re-evaluated. The influence of environmental variables such as $\mathrm{pH}$, temperature, radiation flux, and salt (Cleion) concentration, which can all affect the reaction rate, should be studied systematically. The major oxidants for this reaction in the aqueous phase are $\mathrm{O}_{3}, \mathrm{OH}, \mathrm{HOCl}$, and $\mathrm{OCl}^{-}$. A survey of some known aqueous phase mercury oxidations is given below and also listed in Table A.3.

Commonly implemented (Hedgecock and Pirrone, 2005; Linet al., 2006; Seigneur et al., 2006) rate constants for these reactions are $4.7 \pm 2.2) \times 10^{7} \mathrm{M}^{-1} \mathrm{~s}^{-1}$ for $\mathrm{O}_{3}$ (in the $\mathrm{pH}$ range of $4.5 \mathrm{e} 9.5$ (Munthe, 1992), 2.0 $\times 10^{9} \mathrm{M}^{-1} \mathrm{~s}^{-1}-2.4 \times 10^{10} \mathrm{M}^{-1} \mathrm{~s}^{-1}$ (Gardfeldt et al., 2001; Lin and Pehkonen, 1997) for the $\mathrm{OH}$ radical,2.09 $( \pm 0.06) \times 10^{6} \mathrm{M}^{-1} \mathrm{~s}^{-1}$ for $\mathrm{HOCl}$, and $1.99( \pm 0.05) \times 10^{6} \mathrm{M}^{-1} \mathrm{~s}^{-1}$ for $\mathrm{OCl}^{-}$ 
(C) This manuscript version is made available under the CC-BY-NC-ND 4.0 license https://creativecommons.org/licenses/by-nc-nd/4.0/

https://www.sciencedirect.com/science/article/pii/S1352231011004353

(Lin and Pehkonen, 1998). Recently, the second order rate constants for the aqueous oxidation of mercury by $\mathrm{Br}_{2}, \mathrm{HOBr}$, and $\mathrm{OBr}^{-}$have been reported as $0.20( \pm 0.03), 0.28( \pm 0.02)$, and 0.27 $( \pm 0.04) \mathrm{M}^{-1} \mathrm{~S}^{-1}$, respectively at room temperature (Wangand Pehkonen, 2004). Based on the small rate constants of these reactions and from comparisons with the rate constants of other oxidants, the authors concluded that aqueous phase oxidation of $\mathrm{Hg} 0(\mathrm{~g})$ by $\mathrm{Br} 2, \mathrm{HOBr}$, and $\mathrm{OBr}^{-}$are not a significant source of the mercury depletion observed in the polar regions. To the best of our knowledge there is no kinetic study indicating such oxidation reactions on aerosols in the Arctic, where one has observed the ubiquitous presence of mercury compounds associated with aerosols in aquatic systems (Poulain et al., 2007).

Although elemental mercury is volatile and has poor solubility in water, $49.4 \times 10^{-6} \mathrm{gl}^{-1}$ at $20^{\circ} \mathrm{C}\left(\right.$ Schroeder and Munthe, 1998), the fast oxidation of $\mathrm{Hg}^{0}(\mathrm{~g})$ by these species in the aqueous phase makes the incorporation of these reactions in models important. Moreover, the fast aqueous phase rate is an indication that the oxidation of mercury by these oxidants when adsorbed at the surface of atmospheric water droplets, which is much more prob-able for $\mathrm{Hg}_{(\mathrm{g})}^{0}$ than being dissolved in the aqueous phase, may also occur at a faster rate compared to the pure gas phase reactions. Indeed, as discussed in previous sections, certain product formations are more favourable when in contact with third-body or water. The presence of cloud droplets and aerosol particles contributing to the heterogeneity in the atmosphere renders the aqueous phase and surface oxidation chemistry essential in the atmosphere.

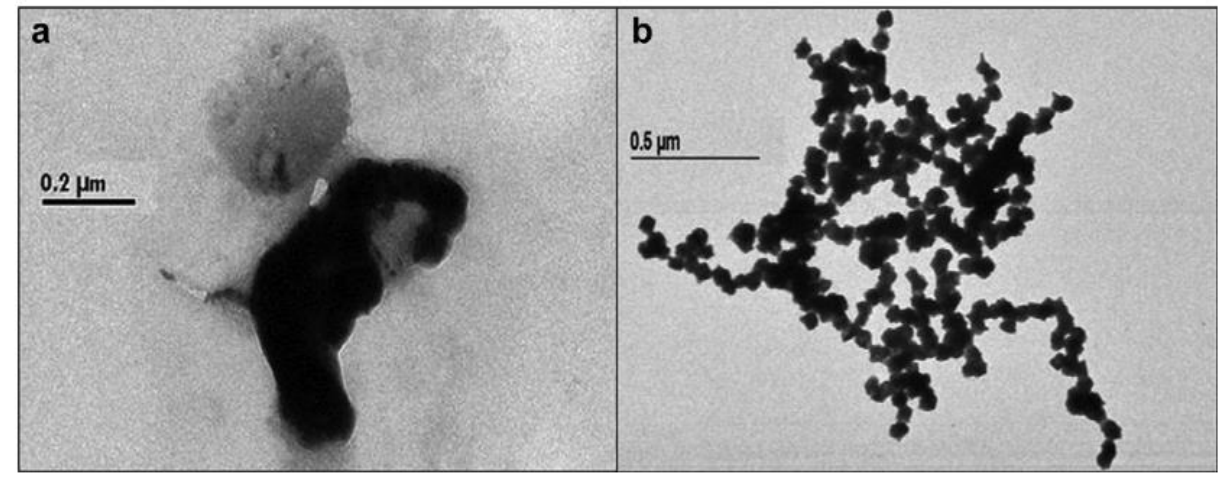

Fig A.1. The influence of surfaces has been observed in laboratory experiments (Ariya et al., 2009a,b; Pal and Ariya, 2004b; Snider et al., 2008). There is evidence of mercury clusters and aerosol formation in the presence of aerosols (a) and on the surface of the reaction chamber (b).

Table A.1

Theoretical and experimental thermodynamic values for selected mercury reactions.

\begin{tabular}{lll}
\hline Reaction & Theoretical change in energy (kcal/mol) & Experimental change in energy (Kcal/mol) \\
\hline $\mathrm{Hg}_{(\mathrm{g})}+\mathrm{O}_{3(\mathrm{~g})} \rightarrow \mathrm{HgO}_{(\mathrm{g})}+\mathrm{O}_{2(\mathrm{~g})}$ & $\Delta G_{\mathrm{tot}}^{298 \mathrm{~K}}=+16.6 \mathrm{a}$ \\
$\mathrm{HgO}_{(\mathrm{g})}+\mathrm{H}_{2} \mathrm{O}_{(\mathrm{g})} \rightarrow \mathrm{Hg}(\mathrm{OH})_{2(\mathrm{~g})}$ & $\Delta G_{\mathrm{tot}}^{29 \mathrm{~K}}=-56.6 \mathrm{a}$ \\
$\mathrm{Hg}_{(\mathrm{g})}+\mathrm{OH}_{(\mathrm{g})} \rightarrow \mathrm{HgO}_{(\mathrm{g})}+\mathrm{H}_{(\mathrm{g})}$ & $\Delta G_{\mathrm{tot}}^{298 K}=+98.5 \mathrm{a}$ \\
$\mathrm{Hg}_{(\mathrm{g})}+\mathrm{OH}_{(\mathrm{g})} \rightarrow \mathrm{HgOH}_{(\mathrm{g})}$ & $\Delta G_{\mathrm{tot}}^{29 \mathrm{~K}}=-1.0 \mathrm{a}$ \\
$\mathrm{Hg}_{(\mathrm{g})}+2 \mathrm{OH}_{(\mathrm{g})} \rightarrow \mathrm{Hg}(\mathrm{OH})_{2(\mathrm{~g})}$ & $\Delta G_{\mathrm{tot}}^{298 K}=-59.0 \mathrm{a}$
\end{tabular}


(C) This manuscript version is made available under the CC-BY-NC-ND 4.0 license https://creativecommons.org/licenses/by-nc-nd/4.0/ https://www.sciencedirect.com/science/article/pii/S1352231011004353

Table A.1 (continued)

\begin{tabular}{|c|c|c|}
\hline Reaction & Theoretical change in energy $(\mathrm{kcal} / \mathrm{mol})$ & Experimental change in energy $(\mathrm{Kcal} / \mathrm{mol})$ \\
\hline $\mathrm{Hg}_{(\mathrm{g})}+2 \mathrm{Br}_{(\mathrm{g})} \rightarrow \mathrm{HgBr}_{2(\mathrm{~g})}$ & $\Delta G_{\mathrm{tot}}^{298 \mathrm{~K}}=-67.6 \mathrm{a}$ & \\
\hline \multirow[t]{2}{*}{$\mathrm{Hg}_{(\mathrm{g})}+\mathrm{Br}_{2(\mathrm{~g})} \rightarrow \mathrm{HgBr}_{(\mathrm{g})}+\mathrm{Br}_{(\mathrm{g})} \rightarrow \mathrm{HgBr}_{2(\mathrm{~g})}$} & $\Delta H_{\mathrm{rxn}}^{\mathrm{OK}}=+30.6 \mathrm{~b}$ & $\Delta H_{\mathrm{r} \times \mathrm{n}}^{0 \mathrm{~K}}=+29 \pm 9 \mathrm{~b} \cdot \mathrm{c}$ \\
\hline & $\Delta H_{\mathrm{r} \times \mathrm{n}}^{\mathrm{OK}}=-42.4 \mathrm{~b}$ & $\Delta H_{\mathrm{rXn}}^{0 \mathrm{~K}}=-42 \pm 2 \mathrm{~b}^{\circ \mathrm{c}}$ \\
\hline \multirow{3}{*}{$\begin{array}{l}\mathrm{Hg}_{(\mathrm{g})}+\mathrm{Br}_{2(\mathrm{~g})} \rightarrow \mathrm{HgBr}_{2(\mathrm{~g})} \\
\mathrm{Hg}_{(\mathrm{g})}+\mathrm{BrO}_{(\mathrm{g})} \rightarrow \mathrm{HgO}_{(\mathrm{g})}+\mathrm{Br}_{(\mathrm{g})}\end{array}$} & $\Delta G_{\mathrm{tot}}^{298 \mathrm{~K}}=-33.8 \mathrm{a}$ & $\Delta G_{\mathrm{tot}}^{298 \mathrm{~K}}=-42.8 \mathrm{c} \cdot \mathrm{d}$ \\
\hline & $\Delta G_{\mathrm{tot}}^{298 \mathrm{~K}}=+49.0 \mathrm{a}$ & $\Delta H_{\mathrm{rxn}}^{0 \mathrm{~K}}=-8 \pm 16 \mathrm{~b}^{\circ} \mathrm{c}$ \\
\hline & $\Delta H_{\mathrm{rxn}}^{0 \mathrm{~K}}=+50.2 \mathrm{~b}$ & \\
\hline \multirow{2}{*}{$\mathrm{Hg}_{(\mathrm{g})}+\mathrm{BrO}_{(\mathrm{g})} \rightarrow \mathrm{HgBr}_{(\mathrm{g})}+\mathrm{O}_{(\mathrm{g})}$} & $\Delta H_{\mathrm{rxn}}^{0 \mathrm{~K}}=+28.5 \mathrm{a}$ & $\Delta H_{\mathrm{rxn}}^{0 \mathrm{~K}}=+39 \pm 10 \mathrm{~b} \cdot \mathrm{c}$ \\
\hline & $\Delta G_{\text {tot }}^{298 \mathrm{~K}}=+39.5 \mathrm{~b}$ & \\
\hline $\mathrm{Hg}_{(\mathrm{g})}+\mathrm{BrO}_{(\mathrm{g})} \rightarrow \mathrm{HgBrO}_{(\mathrm{g})}$ & $\Delta H_{\mathrm{rxn}}^{\mathrm{OK}}=-20.2 \mathrm{~b}$ & \\
\hline \multirow[t]{2}{*}{$\mathrm{Hg}_{(\mathrm{g})}+\mathrm{Br}_{(\mathrm{g})} \rightarrow \mathrm{HgBr}_{(\mathrm{g})}$} & $\Delta G_{\mathrm{tot}}^{298 \mathrm{~K}}=-8.0 \mathrm{a}$ & $\Delta G_{\mathrm{tot}}^{298 \mathrm{~K}}=-16.5 \mathrm{~d} \cdot \mathrm{e}$ \\
\hline & $\Delta G_{\mathrm{tot}}^{298 \mathrm{~K}}=-15.0 \mathrm{~d}$ & \\
\hline $\mathrm{Hg}_{(\mathrm{g})}+\mathrm{BrCl}_{(\mathrm{g})} \rightarrow \mathrm{HgBrCl}_{(\mathrm{g})}$ & $\Delta G_{\mathrm{tot}}^{298 \mathrm{~K}}=-45.3 \mathrm{~b}$ & \\
\hline $\mathrm{HgBr}_{(\mathrm{g})}+\mathrm{Br}_{(\mathrm{g})} \rightarrow \mathrm{HgBr}_{2(\mathrm{~g})}$ & $\Delta H_{\mathrm{rxn}}^{\mathrm{OK}}=-59.7 \mathrm{a}$ & \\
\hline \multirow[t]{2}{*}{$\mathrm{Hg}_{(\mathrm{g})}+\mathrm{Cl}_{(\mathrm{g})} \rightarrow \mathrm{HgCl}_{(\mathrm{g})}$} & $\Delta H_{\mathrm{rxn}}^{\mathrm{OK}}=-11.4 \mathrm{a}$ & $\Delta G_{\mathrm{tot}}^{298 \mathrm{~K}}=-24.9 \mathrm{~d} \cdot \mathrm{e}$ \\
\hline & $\Delta H_{\mathrm{rXn}}^{\mathrm{OK}}=-19.0 \mathrm{~d}$ & \\
\hline $\mathrm{HgCl}_{(\mathrm{g})}+\mathrm{Cl}_{(\mathrm{g})} \rightarrow \mathrm{HgCl}_{2(\mathrm{~g})}$ & $\Delta G_{\mathrm{tot}}^{298 \mathrm{~K}}=-68.2 \mathrm{a}$ & $\Delta G_{\text {tot }}^{298 \mathrm{~K}}=-82.7 \mathrm{~d} \cdot \mathrm{e}$ \\
\hline \multirow[t]{2}{*}{$\mathrm{Hg}_{(\mathrm{g})}+\mathrm{Cl}_{2(\mathrm{~g})} \rightarrow \mathrm{HgCl}_{(\mathrm{g})}+\mathrm{Cl}_{(\mathrm{g})} \rightarrow \mathrm{HgCl}_{2(\mathrm{~g})}$} & $\Delta H_{\mathrm{rxn}}^{0 \mathrm{~K}}=+35.1 \mathrm{~b}$ & $\Delta H_{\mathrm{rxn}}^{\mathrm{OK}}=+32 \pm 2 \mathrm{~b}^{\prime} \mathrm{c}$ \\
\hline & $\Delta H_{\mathrm{rxn}}^{\mathrm{OK}}=-48.7 \mathrm{~b}$ & $\Delta H_{\mathrm{rXn}}^{\mathrm{OK}}=-49 \pm 2 \mathrm{~b} \cdot \mathrm{c}$ \\
\hline $\mathrm{Hg}_{(\mathrm{g})}+\mathrm{ClO}_{(\mathrm{g})} \rightarrow \mathrm{HgClO}_{(\mathrm{g})}$ & $\Delta H_{\mathrm{rxn}}^{\mathrm{OK}}=-21.6 \mathrm{~b}$ & \\
\hline $\mathrm{Hg}_{(\mathrm{g})}+\mathrm{F}_{(\mathrm{g})} \rightarrow \mathrm{HgF}_{(\mathrm{g})}$ & $\Delta G_{\mathrm{tot}}^{298 \mathrm{~K}}=-32.7 \mathrm{~d}$ & $\Delta G_{\mathrm{tot}}^{298 \mathrm{~K}}=-32.9 \mathrm{~d} \cdot \mathrm{e}$ \\
\hline \multirow[t]{2}{*}{$\mathrm{Hg}_{(\mathrm{g})}+\mathrm{I}_{2(\mathrm{~g})} \rightarrow \mathrm{Hgl}_{(\mathrm{g})}+\mathrm{I}_{(\mathrm{g})} \rightarrow \mathrm{Hgl}_{2(\mathrm{~g})}$} & $\Delta H_{\mathrm{rXn}}^{0 \mathrm{~K}}=+27.47 \mathrm{f}$ & $27.7 \pm 0.1 \mathrm{c} \cdot \mathrm{f}$ \\
\hline & $\Delta H_{\mathrm{rXn}}^{0 \mathrm{~K}}=-34.98 \mathrm{f}$ & $-33.4 \pm 0.5 \mathrm{cf}$ \\
\hline
\end{tabular}

a (Tossel, 2003).

b (Balabanov and Peterson, 2003).

c (Chase et al., 1985).

d (Khalizov et al., 2003).

' (Chase, 1998).

f (Shepler et al., 2005).

Table A.2

Comparison of theoretical and experimental rate constants for elemental mercury oxidation reactions at $25^{\circ} \mathrm{C}$ (or otherwise stated).

\begin{tabular}{|c|c|c|}
\hline Reaction & Theoretical rate constants $\mathrm{k}\left(\mathrm{cm}^{3}\right.$ molec $\left.^{-1} \mathrm{~s}^{-1}\right)$ & Experimental rate constant $\mathrm{k}\left(\mathrm{cm}^{3} \mathrm{molec}^{-1} \mathrm{~s}^{-1}\right)$ \\
\hline \multirow[t]{5}{*}{$\mathrm{Hg}_{(\mathrm{g})}+\mathrm{Br}_{(\mathrm{g})} \rightarrow \mathrm{HgBr}_{(\mathrm{g})}$} & $\begin{array}{l}2.1 \times 10^{-12} \\
\operatorname{CCSD}(\mathrm{T})\end{array}$ & $3.6( \pm 0.9) \times 10^{-13}$ (abs) (Donohoue et al., 2006) \\
\hline & $\begin{array}{l}\text { CVTST and capture model (Khalizov et al., 2003) } \\
1.1 \times 10^{-12}\end{array}$ & $3.2( \pm 0.3) \times 10^{-12}($ rel $)$ (Ariya et al., 2002) \\
\hline & B3LYP/RRKM (Goodsite et al., 2004) & $9.7 \times 10^{-13}(\mathrm{rel})($ Spicer, 2002) \\
\hline & $9.8 \times 10^{-13}$ (at 1 bar $)$ & $3.0 \times 10^{-13}(\mathrm{rel})($ Spicer, 2002) \\
\hline & Quasi-CT (Shepler et al., 2007a,b) & $6.4( \pm 4.2) \times 10^{-13}(\mathrm{rel})($ Sumner et al., 2011) \\
\hline $\mathrm{HgBr}_{(g)}+\mathrm{Br}_{(g)} \rightarrow \mathrm{HgBr}_{(g)}+\mathrm{Br}_{2(g)}$ & $3.9( \pm 0.2) \times 10^{-11} \mathrm{MRCI} /$ Quasi-CT (Balabanov et al., 2005) & \\
\hline $\mathrm{HgBr}_{(\mathrm{g})}+\mathrm{Br}_{(\mathrm{g})} \rightarrow \mathrm{HgBr}_{2(\mathrm{~g})}$ & $3.0( \pm 0.1) \times 10^{-11} \mathrm{MRCI} /$ Quasi-CT (Balabanov et al., 2005) & $7 \times 10^{-17}(\mathrm{abs})$ at $397 \mathrm{~K}$ (Greig et al., 1970a) \\
\hline $\mathrm{BrHg}_{(\mathrm{g})}+\mathrm{Br}_{(\mathrm{g})} \rightarrow \mathrm{HgBr}_{(\mathrm{g})}+\mathrm{Br}_{(\mathrm{g})}$ & $4.0( \pm 0.4) \times 10^{-11} \mathrm{MRCI} /$ Quasi-CT (Balabanov et al., 2005) & \\
\hline $\mathrm{Hg}_{(\mathrm{g})}+\mathrm{Br}_{2(\mathrm{~g})} \rightarrow \mathrm{HgBr}_{2(\mathrm{~g})}$ & $\begin{array}{l}2.8 \times 10^{-31} \mathrm{MRCI} / \text { microcanonical VTST } \\
\text { (Balabanov et al., 2005) }\end{array}$ & $\begin{array}{l}9 \times 10^{-17} \text { (rel) (Ariya et al., 2002) No Reaction } \\
\text { detected (Sumner et al., 2005) }\end{array}$ \\
\hline $\mathrm{HgCl}_{(\mathrm{g})}+\mathrm{HCl}_{(\mathrm{g})} \rightarrow \mathrm{HgCl}_{2(\mathrm{~g})}+\mathrm{H}_{(\mathrm{g})}$ & $1.5 \times 10^{-33}$ QCISD $/ 1997 / T S T$ (Wilcox et al., 2003) & $1 \times 10^{-19}($ Hall and Bloom, 1993) \\
\hline $\mathrm{HgCl}_{(\mathrm{g})}+\mathrm{HCl}_{(\mathrm{g})}+\mathrm{M} \rightarrow \mathrm{HgCl}_{2(\mathrm{~g})}$ & $1.6 \times 10^{-26}$ QCISD $/ 1997 / T S T$ (Wilcox et al., 2003) & \\
\hline $\mathrm{Hg}_{(\mathrm{g})}+\mathrm{Cl}_{(\mathrm{g})} \rightarrow \mathrm{HgCl}_{(\mathrm{g})}$ & $\begin{array}{l}2.8 \times 10^{-12} \operatorname{CCSD}(\mathrm{T}) \text { CVTST and capture model } \\
\text { (Khalizov et al., 2003) }\end{array}$ & $\begin{array}{l}5.4 \times 10^{-13} \text { (abs) (Donohoue et al., 2005) } \\
1.0( \pm 0.2) \times 10^{-11} \text { (rel) (Ariya et al., 2002) } \\
8.4( \pm 1.1) \times 10^{-11} \text { (Sumner et al., 2011) }\end{array}$ \\
\hline $\mathrm{Hg}_{(\mathrm{g})}+\mathrm{F}_{(\mathrm{g})} \rightarrow \mathrm{HgF}_{(\mathrm{g})}$ & $\begin{array}{l}1.9 \times 10^{-12} \operatorname{CCSD}(\mathrm{T}) \text { CVTST and capture model } \\
\text { (Khalizov et al., 2003) }\end{array}$ & No reaction detected (Sumner et al., 2011) \\
\hline $\mathrm{Hg}_{(\mathrm{g})}+\mathrm{OH}_{(\mathrm{g})} \rightarrow \mathrm{HgOH}_{(\mathrm{g})}$ & $3.2 \times 10^{-13}$ B3LYP/RRKM (Goodsite et al., 2004) & $\begin{array}{l}9.0( \pm 1.3) \times 10^{-14}(\mathrm{rel})(\text { Pal and Ariya, 2004a) } \\
8.7( \pm 2.8) \times 10^{-14}(\mathrm{rel})(\text { Sommar et al., 2001) } \\
<1.2 \times 10^{-13}(\text { abs })(\text { Bauer et al., 2003) }\end{array}$ \\
\hline $\mathrm{Hg}_{(\mathrm{g})}+\mathrm{O}_{3(\mathrm{~g})} \rightarrow \mathrm{HgO}_{(\mathrm{g})}+\mathrm{O}_{2(\mathrm{~g})}$ & $\begin{array}{l}3.1 \times 10^{-40} \mathrm{QCIS}(\mathrm{T}) / \mathrm{MP} 2 ; \mathrm{TST} \text { theory } \\
\text { (Xu et al., 2008) }\end{array}$ & $\begin{array}{l}7.5( \pm 0.9) \times 10^{-19}(\text { abs }) \text { (Pal and Ariya, 2004b) } \\
6.4( \pm 2.3) \times 10^{-19} \text { (abs) (Sumner et al., 2005) } \\
8.4 \times 10^{-18}(303 \mathrm{~K})(\text { P'yankov, 1949) } \\
4.2 \times 10^{-19}(293 \mathrm{~K}) \text { (P'yankov, 1949; Slemr et al., 1985) } \\
4.9 \times 10^{-18}(293 \mathrm{~K})(\text { Schroeder et al., 1991) (abs, re-plotted) } \\
\sim 1.7 \times 10^{-18}(293 \mathrm{~K}) \text { (Iverfeldt and Lindqvist, 1986) }\end{array}$ \\
\hline
\end{tabular}


(C) This manuscript version is made available under the CC-BY-NC-ND 4.0 license https://creativecommons.org/licenses/by-nc-nd/4.0/

https://www.sciencedirect.com/science/article/pii/S1352231011004353

Table A.3

Aqueous phase mercury oxidation and reduction reactions commonly implemented in mercury models.

\begin{tabular}{|c|c|}
\hline & Rate constant \\
\hline \multicolumn{2}{|l|}{ Oxidation reactions } \\
\hline $\mathrm{Hg}_{(\mathrm{aq})}^{0}+\mathrm{O}_{3(\mathrm{aq})} \rightarrow \mathrm{HgO}_{(\mathrm{aq})}$ & $4.7( \pm 2.2) \times 10^{7} \mathrm{M}^{-1} \mathrm{~s}^{-1}$ (Munthe, 1992$)$ \\
\hline $\mathrm{Hg}_{(\mathrm{aq})}^{0}+\mathrm{OH}_{(\mathrm{aq})} \rightarrow \mathrm{Hg}_{(\mathrm{aq})}^{11}$ & $2.4 \times 10^{9} \mathrm{M}^{-1} \mathrm{~s}^{-1}$ (Gardfeldt et al., 2001) \\
\hline $\mathrm{Hg}_{(a q)}^{0}+\mathrm{OH}_{(a q)} \rightarrow \mathrm{Hg}_{(a q)}^{+}+\mathrm{OH}_{(a q)}^{-}$ & $2.4( \pm 0.3) \times 10^{10} \mathrm{M}^{-1} \mathrm{~s}^{-1}($ Lin and Pehkonen, 1997$)$ \\
\hline $\mathrm{Hg}_{(\mathrm{aq})}^{0}+\mathrm{HOCl}_{(\mathrm{aq})} \rightarrow \mathrm{Hg}_{(\mathrm{aq})}^{2+}+\mathrm{Cl}_{(\mathrm{aq})}^{-}+\mathrm{OH}_{(\mathrm{aq})}^{-}$ & $2.09( \pm 0.06) \times 10^{6} \mathrm{M}^{-1} \mathrm{~s}^{-1}($ Lin and Pehkonen, 1998) \\
\hline $\mathrm{Hg}_{(\mathrm{aq})}^{0}+\mathrm{OCl}_{(\mathrm{aq})}^{-} \rightarrow \mathrm{Hg}_{(\mathrm{aq})}^{2+}+\mathrm{Cl}_{(\mathrm{aq})}^{-}+\mathrm{OH}_{(\mathrm{aq})}^{-}$ & $1.99( \pm 0.05) \times 10^{6} \mathrm{M}^{-1} \mathrm{~s}^{-1}($ Lin and Pehkonen, 1998$)$ \\
\hline $\mathrm{Hg}_{(\mathrm{aq})}^{+}+\mathrm{Br}_{2(\mathrm{aq})} \rightarrow \mathrm{Hg}_{(\mathrm{aq})}^{2+}+2 \mathrm{Br}_{(\mathrm{aq})}^{-}$ & $0.20( \pm 0.03) \mathrm{M}^{-1} \mathrm{~s}^{-1}($ Wang and Pehkonen, 2004) \\
\hline $\mathrm{Hg}_{(\mathrm{aq})}^{+}+\mathrm{HOBr}_{(\mathrm{aq})} \rightarrow \mathrm{Hg}_{(\mathrm{aq})}^{2+}+\mathrm{OH}_{(\mathrm{aq})}^{-}+\mathrm{Br}_{(\mathrm{aq})}^{-}$ & $0.28( \pm 0.02) \mathrm{M}^{-1} \mathrm{~s}^{-1}$ (Wang and Pehkonen, 2004) \\
\hline $\mathrm{Hg}_{(\mathrm{aq})}^{+}+\mathrm{OBr}_{(\mathrm{aq})}^{-} \rightarrow \mathrm{Hg}_{(\mathrm{aq})}^{2+}+2 \mathrm{Br}_{(\mathrm{aq})}^{-}$ & $0.27( \pm 0.04) \mathrm{M}^{-1} \mathrm{~s}^{-1}($ Wang and Pehkonen, 2004) \\
\hline \multicolumn{2}{|l|}{ Reduction reactions } \\
\hline $\mathrm{Hg}_{(\mathrm{aq})}^{2+}+\mathrm{HO}_{2(\mathrm{aq})} \rightarrow \mathrm{Hg}_{(\mathrm{aq})}^{+}+\mathrm{O}_{2(\mathrm{aq})}+\mathrm{H}_{(\mathrm{aq})}^{+}$ & 0 or $1.1 \times 10^{4} \mathrm{M}^{-1} \mathrm{~s}^{-1}$ (Gardfeldt and Jonsson, 2003; Pehkonen and Lin, 1998) \\
\hline $\begin{array}{l}\mathrm{Hg}_{(\mathrm{aq})}^{2+}+\mathrm{O}_{2(\mathrm{aq})}^{-} \rightarrow \mathrm{Hg}_{(\mathrm{aq} q}^{+}+\mathrm{O}_{2(\mathrm{aq})} \\
\mathrm{HgSO}_{3(\mathrm{aq})} \rightarrow \mathrm{Hg}_{(\mathrm{aq})}^{0}+\mathrm{S}(\mathrm{VI})\end{array}$ & $\begin{array}{l}0 \text { or } 1.1 \times 10^{4} \mathrm{M}^{-1} \mathrm{~s}^{-1} \text { (Gardfeldt and Jonsson, 2003; Pehkonen and Lin, 1998) } \\
0.0106 \mathrm{~s}^{-1} \text { (Van Loon et al., 2000) } \\
0.6 \mathrm{~s}^{-1} \text { (Munthe et al., 1991) }\end{array}$ \\
\hline $\mathrm{Hg}\left(\mathrm{SO}_{3}\right)_{2(\mathrm{aq})}^{2-} \rightarrow \mathrm{Hg}_{(\mathrm{aq})}^{0}+\mathrm{S}(\mathrm{VI})$ & $<<10^{-4} \mathrm{~s}^{-1}$ (Munthe et al., 1991) \\
\hline $\mathrm{Hg}(\mathrm{OH})_{2(\mathrm{aq})}+\mathrm{UV} \rightarrow \mathrm{Hg}_{(\mathrm{aq})}^{0}+$ Products & $3.7 \times 10^{-7} \mathrm{~s}^{-1}($ Xiao et al., 1994) \\
\hline
\end{tabular}

\section{References}

Ariya, P.A., 2010. Atmospheric science: mid-latitude mercury loss. Nature Geoscince4, 14-15

Ariya, P.A., Peterson, K.A., 2005. Chemical Transformation of Gaseous Elemental Mercury in the Atmosphere. Springer, New York

Ariya, P.A., Ryzhkov, A., 2003. Atmospheric transformation of elemental mercury with halogens. J. Phys. IV France 107, 57-59.

Ariya, P.A., Skov, H., Mette, M.-L.G., Goodsite, M.E., 2008. Gaseous Elemental Mercury in the Ambient Atmosphere: Review of the Application of Theoretical Calculations and Experimental Studies for Determination of Reaction Coefficients and Mechanisms with Halogens and Other Reactants. Academic Press.

Ariya, P.A., Khalizov, A., Gidas, A., 2002. Reactions of gaseous mercury with atomic and molecular halogens: kinetics, product studies, and atmospheric implications. Journal of Physical Chemistry A 106, 7310-7320.

Ariya, P.A., Peterson, K., Snider, G., Amyot, M., 2009a. Mercury chemical trans-formation in the gas, aqueous and heterogeneous phases: state-of-the-art science and uncertainties. In: Pirrone, N., Mason, R. (Eds.), Mercury Fate and Transport in the Global Atmosphere. Springer, New York.

Ariya, P.A., Sun, J., Eltouny, N.A., Hudson, E.D., Hayes, C.T., Kos, G., 2009b. Physical and chemical characterization of bioaerosols-implications for nucleation processes. International Review in Physical Chemistry 28, 1-32.

Balabanov, N.B., Peterson, K.A., 2003. Mercury and reactive halogens: the thermo-chemistry of $\mathrm{Hg}+\left\{\mathrm{Cl}_{2}, \mathrm{Br} 2, \mathrm{BrCl}, \mathrm{ClO}\right.$, and $\left.\mathrm{BrO}\right\}$. J. Phys. Chem. A 107,7465-7470. 
(C) This manuscript version is made available under the CC-BY-NC-ND 4.0 license https://creativecommons.org/licenses/by-nc-nd/4.0/

https://www.sciencedirect.com/science/article/pii/S1352231011004353

Balabanov, N.B., Shepler, B.C., Peterson, K.A., 2005. Accurate global potential energy surface and reaction dynamics for the ground state of $\mathrm{HgBr} 2$. J. Phys. Chem. A10, 8765-8773.

Bauer, D., D’Ottone, L., Campuzano-Jost, P., Hynes, A.J., 2003. Gas phase elemental mercury: a comarison of LIF Detection techniques and study of the kinetics of reaction with the hydroxyl radical. Journal of Photochemistry and Photobiology A: Chemistry 157, 247-256.

Bergan, T., Rodhe, H., 2001. oxidation of elemental mercury in the atmosphere; constraints imposed by global scale modelling. Journal of Atmospheric Chemistry 40, 191-212.

Bullock, O.R., 2004. Aqueous reduction of $\mathrm{Hg}^{2+}$ to $\mathrm{Hg}^{0}$ by $\mathrm{HO}_{2}$ in the CMAQ-Hg model. RMZ Mater. Geoenviron 51, 1527-1530.

Bullock, R., 2005. Modelling transport and transformation of $\mathrm{Hg}$ and its compounds in continental air mass. In: Pirrone, N., Mahaffey, K.R. (Eds.), Dynamics of Mercury Pollution on Regional and Global Scales. Springer, New York

Calhoun, J.A., Prestbo, E.M., 2001. Kinetic Study of the Gas Phase Oxidation of Elemental Mercury by Molecular Chlorine. Frontier Geoscience, Inc.

Calvert, J.G., Lindberg, S.E., 2005. Mechanisms of mercury removal by O3and OH in the atmosphere. Atmospheric Environment 39, 3355-3367.

Chase Jr., M.W., 1998. J. Phys. Chem. Ref. Data Monongraph 9.

Chase Jr., M.W., Davies, C.A., Downey Jr., J.R., Frurip, D.J., McDonald, R.A.,Syverud, A.N., 1985. J. Phys. Chem. Ref. Data 14.

Clever, H.L., Johnson, S.A., Derrick, M.E., 1985. The solubility of mercury and some sparingly soluble mercury salts in water and aqueous electrolyte solutions. J. Phys. Chem. Ref. Data 14, 631-680.

Dastoor, A.P., Davignon, D., 2009. Global mercury modelling at environment canada. In: Pirrone, N., Mason, R. (Eds.), Mercury Fate and Transport in the Global Atmosphere. Springer, New York.

Donohoue, D.L., Bauer, D., Hynes, A.J., 2005. Donohoue et al - temperature and pressure dependent rate coefficients for the reaction of $\mathrm{Hg}$ with $\mathrm{Cl}$ and the reaction of $\mathrm{Cl}$ with $\mathrm{Cl}$ : a pulsed laser photolysis-pulsed laser induced fluorescence study. J. Phys. Chem. A 109, 7732-7741.

Donohoue, D.L., Bauer, D., Cossairt, B., Hynes, A.J., 2006. Temperature and pressure dependent rate coefficients for the reaction of $\mathrm{Hg}$ with $\mathrm{Br}$ and the reaction of Brwith $\mathrm{Br}$ : a pulsed laser photolysis-pulsed laser induced fluorescence study. J. Phys. Chem. A 110, 6623-6632. 
(C) This manuscript version is made available under the CC-BY-NC-ND 4.0 license https://creativecommons.org/licenses/by-nc-nd/4.0/

https://www.sciencedirect.com/science/article/pii/S1352231011004353

Feller, D., 2007. Probing the limits of accuracy in electronic structure calculations: is theory capable of results uniformly better than chemical accuracy? The Journal of Chemical Physics $126,1-13$.

Finlayson-Pitts, B.J., James N Pitts, J., 1986. Atmospheric Chemistry: Fundamentals and Experimental Techniques. John Wiley \& Sons, New York.

Flora, S.D., Bennicelli, C., Bagnasco, M., 1994. Genotoxicity of mercury compounds. A review. Mutation Research 371, 57-79.

Gardfeldt, K., Jonsson, M., 2003. Is bimolecular reduction of divalent mercury complexes possible in aqueous systems of environmental importance. J. Phys. Chem. A 107, 4478-4482.

Gardfeldt, K., Sommar, J., Stromberg, D., Feng, X., 2001. Oxidation of atomic mercury by hydroxyl radicals and photoinduced decomposition of methylmercury in the aqueous phase. Atmospheric Environment 35, 3039-3047.

Goodsite, M.E., Plane, J.M.C., Skov, H., 2004. A theoretical study of the oxidation of $\mathrm{Hg}^{0}$ to $\mathrm{HgBr}_{2}$ in the troposphere. Environ. Sci. Technol 38, 1772-1776.

Greig, G., Gunning, H.E., Strausz, O.P., 1970a. Reactions of metal atoms II. The Combination of Mercury and Bromine Atoms and the Dimerization of $\mathrm{HgBr}$. TheJournal of Chemical Physics 52, 3684-3690.

Greig, G., Gunning, H.E., Strausz, O.P., 1970b. Reactions of metal atoms. III. The combination of mercury and iodine atoms and the spectrum of HgI. The Journal of Chemical Physics 52, 4569-4571.

Hall, B., 1995. The gas phase oxidation of elemental mercury by ozone. Water, Air, and Soil Pollution 80, 301-315.

Hall, B., Bloom, N.,1993. Investigation of the Chemical Kinetics of Mercury Reactions Report to EPRI, Palo Alto, California.

Hedgecock, I.M., Pirrone, N., 2005. Modelling chemical and physical processes of $\mathrm{Hg}$ compounds in the marine boundary layer. In: Pirrone, N., Mahaffey, K.R. (Eds.), Dynamics of Mercury Pollution on Regional and Global Scales: Atmospheric Processes and Human Exposures Around the World. Springer, New York.

Hepler, L.G., Olofsson, G., 1975. Mercury: thermodynamic properties, chemical Equilibria, and Standard potentials. Chemical Reviews 75, 585-602.

Holmes, C.D., Jacob, D.J., Yang, X., 2006. Global Lifetime of elemental mercury against oxidation by atomic bromine in the free troposphere. Geophysical Research Letters 33, 1-5. 
(C) This manuscript version is made available under the CC-BY-NC-ND 4.0 license https://creativecommons.org/licenses/by-nc-nd/4.0/

https://www.sciencedirect.com/science/article/pii/S1352231011004353

Horne, D.G., Gosavi, R., Strausz, O.P.,1968. Reaction of metal atoms I. Combination of mercury and chlorine atoms and dimerization of $\mathrm{HgCl}$. The Journal of Chemical Physics 48, 4758-4764.

Hynes, A.J., Donohoue, D.L., Goodsite, M.E., Hedgecock, I.M., 2009. Our current understanding of major chemical and physical processes affecting mercury dynamics in the atmosphere and at the air-water/terrestrial interfaces. In: Pirrone, N., Mason, R. (Eds.), Mercury Fate and Transport in the Global Atmosphere. Springer, New York, pp. 427-457.

Iverfeldt, A., Lindqvist, O., 1986. Atmospheric oxidation of elemental mercury by ozone in the aqueous phase. Atmospheric Environment 20, 1567-1573.

Khalizov, A.F., Viswanathan, B., Larregaray, P., Ariya, P.A., 2003. A theoretical study on the reactions of $\mathrm{Hg}$ with halogens: atmospheric implications. J. Phys. Chem.A 107, 6360-6365.

Kunkely, H., Horvath, O., Vogler, A., 1997. Photophysics and photochemistry of mercury complexes. Coordination Chemistry Reviews 159, 85-93.

Lahoutifard,N., Poissant, L., Scott,S.L., 2003.Heterogeneousscavengingofatmosphericmercury by snow spiked with hydrogen peroxide. J. Phys. IV France 107, 71-714.

Lahoutifard, N., Poissant, L., Scott, S.L., 2006. Scavenging of gaseous mercury by acidic snow at Kuujjuarapik, Norther Quebec. Science of the Total Environment355, 118-126.

Levine, J.S., 1985. The photochemistry of the early atmosphere. In: Levine, J.S. (Ed.),The Photochemistry of Atmospheres: Earth, The Other Planets, and Comets. Academic Press, New York.

Levine, I.N., 2002. Physical Chemistry, fifth ed. McGraw Hill, New York.

Levine, I.N., 2009. Quantum Chemistry. Pearson Prentice Hall, Upper SaddleRiver, NJ.

Lin, C.J., Pehkonen, S.O., 1997. aqueous free radical chemistry of mercury in the presence of iron oxides and ambient aerosol. Atmospheric Environment 31,4125-4137.

Lin, C.-J., Pehkonen, S.O., 1998. Oxidation of elemental mercury by aqueous chlorine $\left(\mathrm{HOCl} / \mathrm{OCl}^{-}\right)$: implications for tropospheric mercury chemistry. Journal of Geophysical Research 103, 28093-28102.

Lin, C.J., Pehkonen, S.O., 1999. The chemistry of atmospheric mercury: a review. Atmospheric Environment 33, 2067-2079.

Lin, C.-J., Pongprueksa, P., Lindberg, S.E., Pehkonen, S.O., Byun, D., Jang, C., 2006.scientific uncertainties in atmospheric mercury models I: model science evaluation. Atmospheric Environment 40, 2911-2928. 
(C) This manuscript version is made available under the CC-BY-NC-ND 4.0 license https://creativecommons.org/licenses/by-nc-nd/4.0/

https://www.sciencedirect.com/science/article/pii/S1352231011004353

McQuarrie, D.A., Simon, J.D., 1997. Physical Chemistry: A Molecular Approach. University

Science Books, Sausalito, California.

Medhekar, A.K., et al., 1979. Surface catalyzed reaction of $\mathrm{Hg}+\mathrm{Cl}_{2}$. Chemical Physics Letter 65, 600-604.

Menke, R., Wallis, G., 1980. Detection of mercury in air in the presence of chlorine and water vapor. American Industrial Hygiene Association Journal 41, 120-124.

Munthe, J., 1992. The aqueous oxidation of elemental mercury by ozone. Atmospheric Environment 26A, 1461-1468.

Munthe, J., Xiao, Z.F., Lindqvist, O., 1991. The aqueous reduction of divalent mercury by sulfite. Water, Air, and Soil Pollution 56, 621-630.

Nazhat, N.B., Asmus, K.D., 1973. Reduction of mercuric chloride by hydrated electrons and reducing radicals in aqueous solutions. formation and reactions of $\mathrm{HgCl}$. The Journal of Physical Chemistry 77, 614-620.

Obrist, D., Tas, E., Peleg, M., Matveev, V., Fain, X., Asaf, D., Luria, M., 2011. bromine-induced oxidation of mercury in the mid-latitude atmosphere. Nature Geo-scince 4, 22-26.

Pai, P., Karamchandani, P., Seigneur, C., 1997. Simulation of the regional atmospheric transport and fate of mercury using a comprehensive eulerian model. Atmospheric Environment 31, 27172732 .

Pal, B., Ariya, P.A., 2004a. Gas-phase $\mathrm{HO}^{\circ}$-initiated reactions of elemental mercury:kinetics, product studies, and atmospheric implications. Environ. Sci. Technol38, 5555-5566.

Pal, B., Ariya, P.A., 2004b. Studies of ozone initiated reactions of gaseous mercury:kinetics, product studies, and atmospheric implications. PCCP 6, 572-579.

Pehkonen, S.O., Lin, C.J., 1998. Aqueous photochemistry of divalent mercury with organic acids. Journal of the Air \& Waste Management Association 48, 144-150.

Pirrone, N., Mahaffey, K.R., 2005. Dynamics of mercury pollution on regional and global scales: atmospheric processes and human exposures around the world. Springer, New York.

Pirrone, N., Mason, R., 2009. Mercury fate and transport in the atmosphere: emissions, measurements and models. Springer, New York.

Poulain, A.J., Garcia, E., Amyot, M., Campbell, P.G.C., Ariya, P.A., 2007. Mercury distribution, partitioning and speciation in coastal vs. inland high arctic snow. Geochimica et Cosmochimica Acta 71, 3419-3431. 
(C) This manuscript version is made available under the CC-BY-NC-ND 4.0 license https://creativecommons.org/licenses/by-nc-nd/4.0/

https://www.sciencedirect.com/science/article/pii/S1352231011004353

P'yankov, V.A., 1949. Kinetics of the reaction between mercury vapor and ozone. Zhurnal Obshchei Khimii. (Journal of General Chemistry) 19, 187-192.

Pyykko, P., 1988. Relativistic effects in structural chemistry. Chem. Rev. 88,563-594.

Raofie, F., Ariya, P.A., 2003. Kinetics and products study of the reaction of BrO radicals with gaseous mercury. Journal de Physique IV France 107, 1119-1121.

Raofie, F., Ariya, P.A., 2004. Product study of the gas-phase BrO-initiated oxidation of Hg: evidence for stable Hg1pcompounds. Environ. Sci. Technol 38,4319-4326.

Raofie, F., Snider, G., Ariya, P.A., 2008. Reaction of gaseous mercury with molecular iodine, atomic iodine, and iodine oxide radicals - kinetics, product studies, and atmospheric implications. Can. J. Chem. 86, 811-820.

Schroeder, W.H., Munthe, J., 1998. Atmospheric mercury - an overview. Atmospheric Environment 32, 809-822.

Schroeder, W.H., Yarwood, G., Niki, H., 1991. Transformation processes involving mercury species in the atmosphere - results from a literature survey. Water, Air, and Soil Pollution 56, 653-666.

Seigneur, C., Vijayaraghavan, K., Lohman, K., 2006. Atmospheric mercury chemistry: sensitivity of global model simulations to chemical reactions. Geophysical Research 111, 1-17.

Seigneur, C., Vijayaraghavan, K., Lohman, K., Levin, L., 2009. The AER/EPRI global chemical transport model for mercury (CTM-HG). In: Pirrone, N., Mason, R.(Eds.), Mercury Fate and Transport in the Global Atmosphere. Springer, New York.

Seignuer, C., Jacek, W., Elpida, C., 1994. A chemical kinetic mechanism for atmospheric inorganic mercury. Environ. Sci. Technol 28, 1589-1597.

Selin, N.E., 2009. Global biogeochemical cycling of mercury: a review. Annu. Rev.Environ. Resourc. 34, 43-63.

Senior, C.L., Sarofim, A.F., Zeng, T., Helble, J.J., Mamani-Paco, R., 2000. Gas-phase transformations of mercury in coal-fired power plants. Fuel Processing Tech-nology 63, $197-$ 213.

Shepler, B.C., Peterson, K.A., 2003. Mercury monoxide: a systematic investigation of its ground electronic state. Journal of Physical Chemistry A 107, 1783-1787.

Shepler, B.C., Balabanov, N.B., Peterson, K.A., 2005. Ab initio thermochemistry involving heavy atoms: an investigation of the reactions $\mathrm{Hg}+\mathrm{IX}(\mathrm{X}=\mathrm{I}, \mathrm{Br}, \mathrm{Cl}, \mathrm{O})$. J. Phys. Chem. A 109, 10363-10372. 
(C) This manuscript version is made available under the CC-BY-NC-ND 4.0 license https://creativecommons.org/licenses/by-nc-nd/4.0/

https://www.sciencedirect.com/science/article/pii/S1352231011004353

Shepler, B.C., Balabanov, N.B., Peterson, K.A., 2007a. $\mathrm{Hg}+\mathrm{Br}->\mathrm{HgBr}$ recombination and collision-induced dissociation dynamics. The Journal of Chemical Physics127, 1-10.

Shepler, B.C., Wright, A.D., Balabanov, N.B., Peterson, K.A., 2007b. Aqueous micro-solvation of mercury halide species. J. Phys. Chem. A 111, 11342-11349.

Skare, I., Hohansson, R., 1992. Reactions between mercury vapor and chlorine gas at occupational exposure levels. Chemosphere 24, 1633-1644.

Slemr, F., Schuster, G., Seiler, W., 1985. Distribution, speciation, and budget of atmospheric mercury. Journal of Atmospheric Chemistry 3, 407e-434.

Sliger, R.N., Kramlich, J.C., Marinov, N.M., 2000. Towards the development of a chemical kinetic model for the homogeneous oxidation of mercury by chlorine species. Fuel Processing Technology 65-66, 423-438.

Snider, G., Raofie, F., Ariya, P.A., 2008. Effects of relative humidity and $\mathrm{CO}(\mathrm{g})$ on the $\mathrm{O}_{3-}$ initiated oxidation reaction of $\mathrm{Hg}^{\mathrm{o}}(\mathrm{g})$ : kinetic and product studies. PCCP 10,5616-5623.

Sommar, J., Hallquist, M., Ljungstrom, E., Lindqvist, O., 1997. On the gas phase reactions between volatile biogenic mercury species and the nitrate radical. Journal of Atmospheric Chemistry 27, 233-247.

Sommar, J., Gardfeldt, K., Stomberg, D., Feng, X., 2001. A kinetic study of the gas-phase reaction between the hydroxyl radical and atomic mercury. Atmospheric Environment 35, 30493054.

Spicer, C.W., 2002. Kinetics of Gas-Phase Elemental Mercury Reaction with Halogen Species, Ozone, and Nitrate Radical under Atmospheric Conditions. Florida Department of Environmental Protection, Tallahassee, FL.

Sumner, A.L., Spicer, C.W., Satola, J., Mangaraj, R., Cowen, K.A., Landis, M.S.,Stevens, R.K., Atkenson, T.D., 2005. Environmental chamber studies of mercury reactions in the atmosphere. In: Pirrone, N., Mahaffey, K.R. (Eds.), Dynamics of Mercury Pollution on Regional and Global Scales: Atmospheric Processes and Human Exposures Around the World. Springer, New York, pp. 193-210.

Sumner, A.L., Spicer, C.W., Landis, M.S., Stevens, R.K., 2011. Kinetics of gaseous elemental mercury oxidation reactions under conditions of relevance to the atmosphere. Atmospheric Environment ATMENV-D-10-01553.

Tokos, J.J.S., Hall, B., Calhoun, J.A., Prestbo, E.M., 1998. Homogeneous gas-phase reaction of $\mathrm{Hg}^{\mathrm{O}}$ with $\mathrm{H}_{2} \mathrm{O}_{2}, \mathrm{O}_{3}, \mathrm{CH}_{3} \mathrm{I}$, and $(\mathrm{CH} 3)_{2} \mathrm{~S}$ : implications for atmospheric $\mathrm{Hg}$ cycling. Atmospheric Environment 32, 823-827. 
(C) This manuscript version is made available under the CC-BY-NC-ND 4.0 license https://creativecommons.org/licenses/by-nc-nd/4.0/

https://www.sciencedirect.com/science/article/pii/S1352231011004353

Tossel, J.A., 2003. Calculation of the energetics for oxidation of gas-phase elemental $\mathrm{Hg}$ by $\mathrm{Br}$ and BrO. The Journal of Physical Chemistry A 107, 7804-7808.

Tossel, J.A., 2006. Calculation of the energetics for the oligomerization of gas phase $\mathrm{HgO}$ and $\mathrm{HgS}$ and for the solvolysis of crystalline $\mathrm{HgO}$ and $\mathrm{HgS}$. Journal of Physical Chemistry A 110, 2571-2578.

Van Loon, L., Mader, E., Scott, S.L., 2000. Reduction of the aqueous mercuric ion by sulfite: UV spectrum of $\mathrm{HgSO}_{3}$ and its intramolecular redox reaction. The Journal of Chemical Physics A $104,1621-1626$.

Wang, Z., Pehkonen, S.O., 2004. Oxidation of elemental mercury by aqueous bromine: atmospheric implications. Atmospheric Environment 38, 3675-3688.

Watras, C.J., Huckabee, J.W.,1994. Mercury Pollution: Integration and Synthesis. CRC Press, Inc., Salem, MA.

Wilcox, J., Robles, J., Marsden, D.C., Blowers, P., 2003. Theoretically predicted rate constants for mercury oxidation by hydrogen chloride in coal combustion flue gases. Environ. Sci. Technol 37, 4199-4204.

Xiao, Z.F., Munthe, J., Stromberg, D., Lindqvist, O., 1994. Photochemical behavior of inorganic mercury compounds in aqueous solution. In: Watras, C.J.,Huckabee, J.W. (Eds.), Mercury as a Global Pollutant - Integration and Synthesis. Lewis Publishers, pp. 581-592.

Xu, M., Qiao, Y., Liu, J., Zheng, C., 2008. Kinetic calculation and modeling of trace Element reactions during combustion. Powder Technology 180, 157-163.

Yan, N.-Q., Liu, S.-H., Chang, S.-G., 2005. Method for the study of gaseous oxidants for the oxidation of mercury gas. Ind. Eng. Chem. Res. 44, 5567-5574.

Zhang, H., 2006. Photochemical redox reactions of mercury. Struct Bond 120,37-79. 
(C) This manuscript version is made available under the CC-BY-NC-ND 4.0 license https://creativecommons.org/licenses/by-nc-nd/4.0/

https://www.sciencedirect.com/science/article/pii/S1352231011004353 